\title{
The Contributions of Prostate Cancer Stem Cells in Prostate Cancer Initiation and Metastasis
}

\author{
Wenjuan Mei ${ }^{1,2,3,4,5}$, Xiaozeng Lin $2,3,4,5$, Anil Kapoor ${ }^{3,4,6}$, Yan Gu 2,3,4,5, Kuncheng Zhao 2,3,4,5 \\ and Damu Tang $2,3,4,5, *$ \\ 1 Department of Nephrology, the First Affiliated Hospital of Nanchang University, Nanchang 330006, China; \\ wenjuanmei1986@gmail.com \\ 2 Department of Medicine, McMaster University, Hamilton, ON L8S 4K1, Canada; linx36@mcmaster.ca (X.L.); \\ yangu0220@gmail.com (Y.G.); kunchengzhao@icloud.com (K.Z.) \\ 3 The Research Institute of St Joe's Hamilton, St Joseph's Hospital, Hamilton, ON L8N 4A6, Canada; \\ akapoor@mcmaster.ca \\ 4 Hamilton Urologic Oncology Research Center (HUORC), St Joseph's Hospital, Hamilton, ON L8N 4A6, \\ Canada \\ 5 The Hamilton Center for Kidney Research, St. Joseph's Hospital, Hamilton, ON L8N 4A6, Canada \\ 6 Department of Surgery, McMaster University, Hamilton, ON L8S 4K1, Canada \\ * Correspondence: damut@mcmaster.ca; Tel.: +1-905-522-1155 (ext. 35168); Fax: +1-905-521-6181
}

Received: 29 January 2019; Accepted: 21 March 2019; Published: 27 March 2019

\begin{abstract}
Research in the last decade has clearly revealed a critical role of prostate cancer stem cells (PCSCs) in prostate cancer (PC). Prostate stem cells (PSCs) reside in both basal and luminal layers, and are the target cells of oncogenic transformation, suggesting a role of PCSCs in PC initiation. Mutations in PTEN, TP53, and RB1 commonly occur in PC, particularly in metastasis and castration-resistant PC. The loss of PTEN together with Ras activation induces partial epithelial-mesenchymal transition (EMT), which is a major mechanism that confers plasticity to cancer stem cells (CSCs) and PCSCs, which contributes to metastasis. While PTEN inactivation leads to PC, it is not sufficient for metastasis, the loss of PTEN concurrently with the inactivation of both TP53 and RB1 empower lineage plasticity in PC cells, which substantially promotes PC metastasis and the conversion to PC adenocarcinoma to neuroendocrine PC (NEPC), demonstrating the essential function of TP53 and RB1 in the suppression of PCSCs. TP53 and RB1 suppress lineage plasticity through the inhibition of SOX2 expression. In this review, we will discuss the current evidence supporting a major role of PCSCs in PC initiation and metastasis, as well as the underlying mechanisms regulating PCSCs. These discussions will be developed along with the cancer stem cell (CSC) knowledge in other cancer types.
\end{abstract}

Keywords: prostate cancer stem cells; prostate cancer initiation; metastasis; partial EMT

\section{Introduction}

Prostate cancer (PC) is the most common male malignancy and a major cause of cancer death in men in the developed world [1]. The prostate gland consists of two layers of epithelial cells, basal and luminal epithelial cells [2]. These two cell types have different properties; the majority of luminal epithelial cells express the androgen receptor (AR) and require AR signaling for survival, while basal epithelial cells are AR-negative, and thus not sensitive to castration [3]. As discovered by Charles Huggins [4,5], PC depends on AR signaling, and shares similarities with luminal epithelial cells. In this regard, human PC is widely viewed as being derived from luminal epithelial cells. Similar to other cancer types, PC displays heterogeneity. Among different cell types, a minor cell population is critical in PC formation, progression, and the formation of the heterogeneous PC mass. This unique cell population is defined as prostate cancer stem cells (PCSCs). In mice, PC can originate from both basal 
and luminal epithelial cells, indicating that PCSCs can be generated from either layer; this is consistent with the content of prostate stem cells (PSCs) in both layers [6].

The cancer stem cell (CSC) model states that CSCs are the driving force of cancer evolution and resistance to therapies. PC develops from high-grade prostatic intraepithelial neoplasia (HGPIN), which progresses to locally invasive carcinoma and then metastatic cancer $[7,8]$. PC predominantly metastasizes to the bone [9]. It was initially observed that surgical castration and estrogen injection resulted in significant tumor regression in 15 of 21 patients with metastatic PC (mPC) [4,5]; this discovery led to androgen deprivation therapy (ADT) as the standard treatment in patients with $\mathrm{mPC}$. ADT showed remarkable response in more than $80 \%$ of patients; however, castration-resistant PCs (mCRPCs) commonly develop [10]. Although numerous treatment options are available for mCRPCs, these treatments can only marginally prolong the median overall survival (OS). Docetaxel-based therapy was reported to extend the median OS of CRPC for approximately three months [11,12], as resistance rapidly develops. The same trend also applies to the more potent second-generation anti-androgens approved by Food and Drug Administration (FDA) in 2011 and 2012 [13,14]. The steroid synthesis inhibitor abiraterone and AR antagonist enzalutamide showed only a four to five-month survival advantage in patients with taxane-resistant mCRPC $[13,14]$. To date, metastasis remains the overarching challenge in PC.

Mechanisms of PC initiation and metastasis have been extensively investigated. While our understanding remains incomplete, this colossal research effort clearly revealed complex mechanisms in play for PC initiation and metastasis. These mechanisms can be converged on regulating PCSC. In this review, we will briefly introduce PCSC, discuss evidence supporting PCSC being an origin of PC (Figure 1A), and review research for PCSCs playing critical roles in PC metastasis (Figure 1A). The underlying mechanisms, limitations, and future perspectives will be covered (Figure 1B).
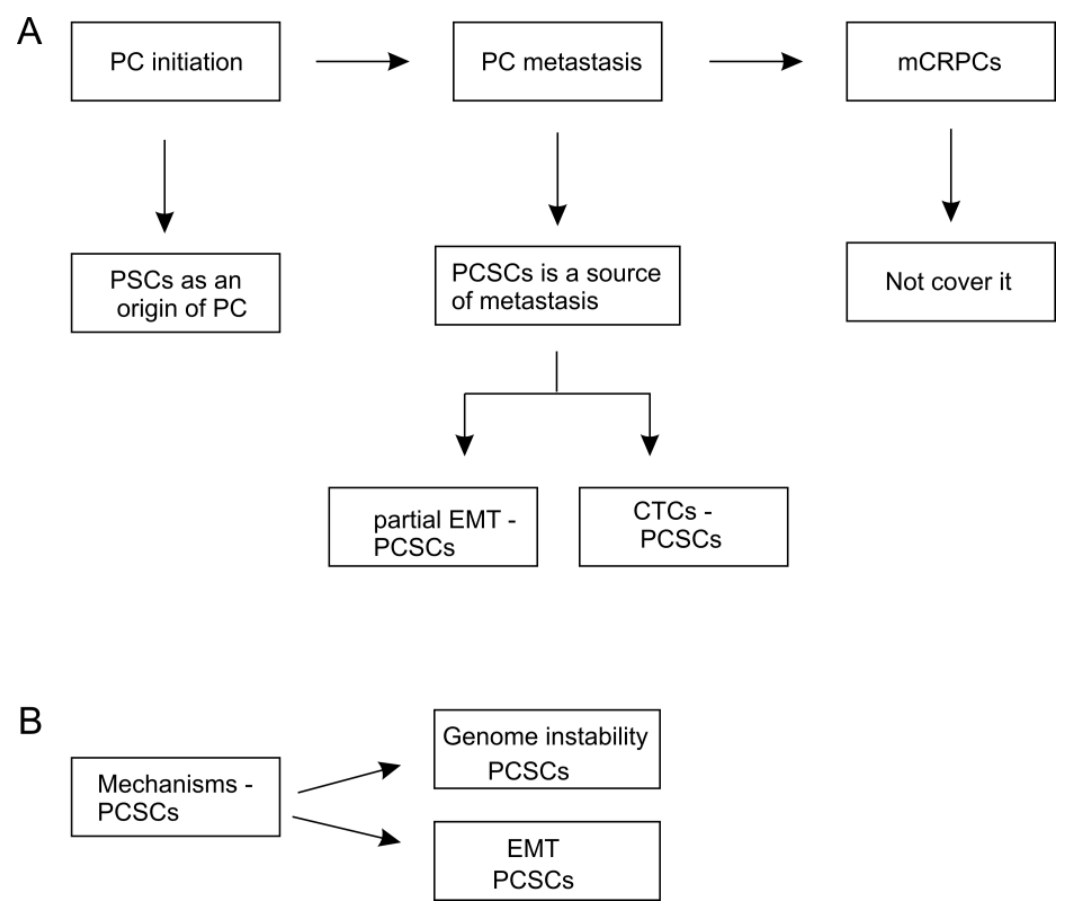

Figure 1. Review manuscript organization. (A) The typical prostate cancer (PC) pathogenesis involves tumor initiation, progression to metastatic diseases, and metastatic castration-resistant prostate cancers (mCRPCs) following androgen deprivation therapy (ADT) treatment. Prostate cancer stem cells (PCSCs) contribute to all these processes; this review will not cover the contributions of PCSCs to CRPC, but rather focus on the other two processes. PSC: prostate stem cells; CTCs: circulating tumor cells. (B) The mechanisms that regulate PCSC stemness will be discussed. 


\section{Identification of PCSCs}

The CSC concept was not novel, but it reinvigorated the field of cancer research following the isolation of $\mathrm{CD} 44^{+} \mathrm{CD} 24^{-/ \text {low }} \mathrm{CSC}$ from primary breast cancer in 2003 by Al-Hajj et al. [15], several years after the establishment of $\mathrm{CD} 34^{+} \mathrm{CD} 38^{-} \mathrm{CSC}$ in acute myeloid leukemia (AML) in 1994 [16]. Since then, CSCs have been isolated in multiple solid cancer types [17,18], including bladder cancer [19], brain tumor [20], colon cancer [21,22], head and neck squamous cell carcinoma [23], liver cancer, lung cancer [24], melanoma [25], pancreatic cancer [26,27], and sarcoma [28]. The initial identification of solid tumor CSCs was largely based on the understanding that CSCs may express a set of surface biomarkers with their tissue stem cells (SCs) [29]. Human prostate SCs are $\alpha_{2} \beta_{1}{ }^{\text {hi CD } 133^{+}}$[30]; PCSCs were identified by Collins et al. in 2005 from primary human PC as $\mathrm{CD} 44^{+} \alpha_{2} \beta_{1}{ }^{\text {hi }} \mathrm{CD} 133^{+}$[31]. It was also reported that PCSCs derived from primary human PCs expressed the breast cancer resistance protein/BCPR (ABCG2) [32]. In both pioneer studies, CD44 ${ }^{+} \alpha_{2} \beta_{1}{ }^{\text {hi }} \mathrm{CD} 133^{+}$ and $\mathrm{BCPR}^{+}$PCSCSs were able to produce other types of PC cells, including those of $\mathrm{AR}^{+}[31,32]$. Subsequently, Trop2 $2^{\text {hi }}$, CD166/ALCAM, PSA ${ }^{-/ \text {low }}$ (prostate-specific antigen), and ALDH1A1 - with the latter being an intracellular protein-have been reported to define PCSCs or be associated with PCSC properties in primary PC [33-36].

PCSCs have also being identified in PC cell lines using cell surface markers and sphere formation assay. $\mathrm{CD} 44^{+}$cells from immortalized human prostate epithelial cells and xenograft tumors were more tumorigenic than their $\mathrm{CD} 44^{-}$counterparts, and exhibited upregulations in stemness genes, including OCT3/4, BMI1, and $\beta$-catenin; CD44 ${ }^{+}$cells were able to produce CD44- PC cells [37]. In LNCaP cells, PSA ${ }^{-/ \text {low }}$ cells displayed PCSC properties [36]. From DU145 cells, PCSCs have been isolated with sphere formation assays; these PCSCs can be maintained for at least 30 passage in 1.5 years without a clear decrease in sphere-forming capacity; the passage is facilitated by EGFR-mediated ERK activation [38]. More importantly, these PCSCs displayed a 100-fold increase in tumor initiation in NOD/SCID mice [39]. DU145 cell-derived PCSCs were CD44 ${ }^{+}$with an elevation in SOX2 expression $[39,40]$. Sphere formation was also used to enrich PCSCs from primary Gleason grades 3 to 5 PCs [41].

\section{PCSCs as a Potential Origin of PC}

The prostate consists of a basal and luminal layer of epithelial cells. To gain insights on PC pathogenesis, one of the key issues is the origin of PC. More relevantly, are PCSCs the origin? While there are no definitive answers, accumulating evidence seems to support this notion.

In AML, transformation of the hematopoietic stem cell causes the disease [42,43]. In solid tumors, the situation is much more complex. In the clinic, a lack of (basal) cells that are positive for the basal epithelial high molecular-weight cytokeratins (CKs) $34 \beta E 12$ has been used as a diagnostic measure to confirm PC [44-47], as human PCs expressed the luminal profile of CKs [48], suggesting the luminal epithelial cells as the target cells for neoplastic transformation [49]. However, in view of PCSCs constituting a small percentage of PC cells and its AR-negative status, the observation that the vast majority of PC cells display luminal epithelial cell CKs does not exclude basal epithelial cells as a possible PC origin. In human prostate, PSCs with the surface antigens of $\alpha_{2} \beta_{1}{ }^{\text {hi }} \mathrm{CD} 133^{+}$are located within the basal layer [30]. Impressively, human prostate epithelial cells could be isolated using CD49f ${ }^{\text {hi }}$ Trop2 ${ }^{\text {hi }}$; these basal epithelial cells, but not luminal epithelial cells, formed a prostate gland structure in the subcutaneous (s.c.) space of NOD/SCID/IL-2R $\gamma^{\text {null }}$ (NSG) mice, confirming the presence of PSCs in the basal layer [50]. Importantly, the ectopic expression of a cocktail of factors including activated AKT (myristoylated AKT), ERG, and AR only in the basal epithelial cells resulted in prostatic intraepithelial neoplasia (PIN) and PCs in NSG mice (Table 1) [50]. This report together with the basal layer location of the identified PCSC surface markers CD $44^{+} \alpha_{2} \beta_{1}{ }^{\text {hi }} \mathrm{CD} 133^{+}$and ABCG2 in the human prostate gland $[31,32]$ support PSCSs being an origin of PC.

This concept is strengthened by investigations using mouse models for PC. By using a variety of surface antigens (Sca-1, CD49f, and Trop2) in combination with a regeneration assay, murine PSCs 
were detected in the basal layer [33,51,52]. Impressively, a single $\mathrm{Lin}^{-} \mathrm{Sca}-1^{+} \mathrm{CD} 133^{+} \mathrm{CD} 44^{+} \mathrm{CD} 117^{+}$ basal cell was able to form prostate when implanted into the renal capsule space of nude mice [53]. Sca- $1^{+}$PSCs not only regenerated prostate glands with engrafts in the renal capsule of SCID mice, but also formed PIN lesions following the ectopic expression of AKT1 [54]. The concomitant expression of AKT and AR in Lin ${ }^{-}$Sca- $1^{+}$CD $49 f^{\text {hi }}$ basal PSCs produced poorly differentiated PC in CB.17 5 SID/SCID mice (Table 1) [55]; the activation of endogenous AKT by the deletion of PTEN caused an expansion of $\mathrm{Lin}^{-} \mathrm{Sca}-1^{+} \mathrm{CD} 49 \mathrm{f}^{\text {hi }}$ basal PSCs, and these PSCs generated PCs following s.c. implantation into SCID mice (Table 1) [56,57]. The location of PCSs in the basal layer was also demonstrated using the lineage-tracing genetic approach [58-60]. Consistent with the above engraft-based studies, the specific deletion of PTEN in the basal epithelial cells was sufficient to induce PC [60,61]. Taken together, PSCs in the basal layer are able to initiate PC in response to PTEN-AKT oncogenic actions.

The luminal layer of the mouse prostate also contains PSCs. The concept of luminal PCSs is supported by the generation of prostate organoids using single luminal epithelial progenitors [62]. Lineage-tracing genetic approaches also revealed PSCs in both the basal and luminal layers, and that the deletion of PTEN in either layer of epithelial cells led to PC (Table 1) [63]. However, it was suggested that basal epithelial cells were more resistant to oncogenic transformation in vivo compared to the luminal epithelial cells [63], which is consistent with the observations that the luminal epithelial cell-originated tumors were more aggressive than those derived from basal epithelial cells [60]. In addition to PTEN deletion, lineage-tracing investigations using $\mathrm{Nkx} 3.1^{+/-}, \mathrm{Hi}-\mathrm{Myc}$, and TRAMP transgenic mice support luminal epithelial cells being prone to PC origination, at least in murine models [64]. In a lineage-tracing effort, it was demonstrated that among the luminal epithelial cells of the mouse prostate, the Nkx3.1 expression cells can self-renew, reconstitute prostate ducts with renal capsule engraft, and initiate PC following PTEN knockout (Table 1) [65]. Additionally, genetically tracing the $\mathrm{BMI}^{+}$lineage of luminal epithelial cells revealed their resistance to castration; these cells possess abilities of self-renewal, tissue regeneration [66], and can generate PC upon PTEN deletion (Table 1) [67]. Interestingly, castration resulted in recurrent PCs (CRPCs) driven by BMI1 $1^{+} \mathrm{SOX} 2^{+}$ cells [67], implying an important role of SOX2 in conferring lineage plasticity in PCSCs. Both BMI1 and SOX2 are well demonstrated for stem cell maintenance and promoting PC [40,68-71]. Furthermore, in the mouse luminal layer, there exists a group of LY6D+ epithelial cells with resistance to castration, PSC capacities, and the ability to produce PIN lesions with PTEN-specific knockout in the cells (Table 1) [72]. Collectively, in approximately $10 \%$ of luminal cells resistant to castration, two different groups of PSCs, $\mathrm{Nkx3.1}^{+}$and BMI1+ [66], along with LY6D+ PSCs, have been identified as origins for PC.

Table 1. PSCs are able to initiate PC.

\begin{tabular}{|c|c|c|c|c|}
\hline Species & PSC $^{1}$ & Oncogenic Signal $^{2}$ & Tumor Model & Ref. \\
\hline Human & Basal CD49f ${ }^{\text {hi }}$ Trop $^{\text {hi }}$ & AKT-ERG-AR & NSG s.c.-xenograft & {$[50]$} \\
\hline Mouse & Basal Lin ${ }^{-}$Sca- $1^{+}$CD $49 f^{h i}$ & AKT1-AR & CB.17SCID/SCID renal capsule & [55] \\
\hline Mouse & Basal Lin ${ }^{-}$Sca- $1^{+}$CD $49 \mathrm{f}^{\text {hi }}$ & PTEN knockout & SCID s.c.-xenograft & [56] \\
\hline Mouse & Basal CK5 $5^{+}$ & PTEN knockout & Lineage-tracing & {$[60]$} \\
\hline Mouse & Basal CK14 ${ }^{+}$ & PTEN knockout & Lineage-tracing & [63] \\
\hline Mouse & Luminal $\mathrm{CK}^{+}$ & PTEN knockout & Lineage-tracing & [63] \\
\hline Mouse & Luminal Nkx3.1expression & $\begin{array}{c}\text { PTEN knockoutNkx3.1 } \\
\text { knockout }\end{array}$ & Lineage-tracing 3 & [65] \\
\hline Mouse & Luminal BMI1 $^{+}$ & PTEN knockout & Lineage-tracing & [67] \\
\hline Mouse & Luminal LY6D ${ }^{+}$ & PTEN knockout & Lineage-tracing-PIN lesion 4 & [72] \\
\hline
\end{tabular}

Thus, evidence supports the existence of luminal and basal stem cells in mouse prostate and its relationship to oncogenic signals (Table 1). For example, the PTEN-AKT axis is tumorigenic when they were directed in these PSCs [64]. However, in human prostate, only the basal epithelial cells are able to regenerate prostate gland structure and produce PC upon receiving ectopic oncogenic signals [50]. 
These discrepancies may be a result of the unique differences in the pathological process between humans and mice. Nonetheless, it was observed that tumors that originated from human basal prostate epithelial cells can be maintained by the luminal cancerous cells of PCSC with SOX2 upregulation [73], suggesting a lineage switch during PC progression. This concept is consistent with the plasticity of SCs and CSCs [74,75], and also suggests that CSCs are evolving during the course of cancer progression. Evidence supporting the evolution of CSCs includes the general intratumoral heterogeneity across multiple tumor types [76,77], the generation of xenograft tumors with different properties from a single lineage [78], and the genomic instability associated with CSCs [79]. Collectively, accumulative evidence suggests a model that alterations in PSCs result in PCSCs that initiate PC. This model is supported by the $\mathrm{Lgr}^{+}$intestine stem cells as an origin of colorectal cancer [80]; glioblastoma requires tissue stem cells, and the ablation of Nestin ${ }^{+}$CSCs caused glioblastoma regression [81].

\section{PCSCs as a Source of PC Metastasis}

Metastasis accounts for more than $90 \%$ of cancer-associated deaths [82,83], and remains the pressing challenge in cancer research. Metastasis is an inefficient process, as it requires the completion of multiple key steps [84]. Tumor cells are disseminated, and enter the blood stream through intravasation, which is a process facilitated by angiogenesis; in the circulation, cancer cells manage to survive and cross the vessel walls into the target organ (extravasation). From there, some cancer cells survive the foreign environment and initiate secondary tumor formation (colonization) $[85,86]$. Leaving the primary site and arriving at the secondary organs require epithelial cancerous cells to undergo epithelial-mesenchymal transition (EMT) $[87,88]$. To grow into metastatic tumors, cancerous cells reverse back to their epithelial status through mesenchymal-epithelial transition (MET) [89,90]. These sequential transitions between EMT (dedifferentiation) and MET (differentiation) are powered by cell plasticity, which is an essential property of CSCs. Additionally, cancerous cells at a foreign site need to be able to initiate tumors, just as in the primary site, in which CSCs are an origin. Collectively, evidence favors an important role of CSC in cancer metastasis [91,92].

\subsection{The Contributions of EMT in PCSCs-Participated Metastasis}

EMT plays a major role in regulating CSC properties [93], and is critical in cancer cell dissemination and its travel to metastatic sites $[87,88]$. By tracing the lineage of mouse pancreatic epithelial cells with KRasG12D expression and p53 knockout, cells with EMT were detected in circulation, which possessed stem cell properties and were able to seed in the liver [94], providing in vivo evidence for EMT promoting the dissemination of cancer cells and their seeding in a metastatic organ. Lineage-tracing mouse models with oncogenic signals directly targeting a particular type of epithelial cells also demonstrated a critical role of EMT in the metastasis of colon cancer, breast cancer, skin squamous cell carcinoma, and prostate cancer [95]. Using mice with prostate-specific $P T E N^{-/-}$and KRasG12D expression together with a vimentin-GFP reporter, Ruscetti et al. reported epithelial tumor cells $\left(\mathrm{EpCAM}^{+} / \mathrm{Vim}^{-\mathrm{GFP}^{-}}\right)$, hybrid EMT $\left(\mathrm{EpCAM}^{+} / \mathrm{Vim}^{-\mathrm{GFP}^{+}}\right)$tumor cells, and mesenchymal-like $\left(\mathrm{EpCAM}^{-} / \mathrm{Vim}^{-\mathrm{GFP}^{+}}\right)$tumor cells $[95,96]$ which likely resulted from a full EMT transition [95]. Both EpCAM ${ }^{+} / \mathrm{Vim}_{-\mathrm{GFP}^{+}}$and $\mathrm{EpCAM}^{-} / \mathrm{Vim}^{-\mathrm{GFP}^{+}}$tumor cells were detected in circulation, exhibited stemness properties, and were much more invasive compared to epithelial tumor cells [96]. Interestingly, the hybrid EMT $\left(\mathrm{EpCAM}^{+} / \mathrm{Vim}_{\left.-\mathrm{GFP}^{+}\right)}\right.$tumor cells but not mesenchymal-like $\left(\mathrm{EpCAM}^{-} / \mathrm{Vim}^{-G_{F P}}\right)^{+}$cells initiated metastatic tumor growth in the lung [96]; these observations indicated that the hybrid EMT PC cells possess lineage plasticity, which mediates MET transition and the subsequent formation of macrometastasis. Similar observations were also reported in hair follicle (HF)-derived squamous cell carcinoma (HF-SCC); hybrid EMT HF-SCCs were more plastic and more aggressive than HF-SCC with full EMT transition $[95,97,98]$. Furthermore, the existence of CTC breast cancer cells with partial EMT was also demonstrated [99]. In a small cohort of 81 PC patients, partial EMT CTCs with the antigen profile of $\mathrm{CK}^{+} / \mathrm{Vim}^{+} / \mathrm{CD} 45^{-}$were associated with metastasis [100]. 
At the center of EMT is a set of core transcription factors (TF) that execute EMT, including SNAIL, TWIST, and ZEB [87]. In human mammary epithelial cells (HMECs), the ectopic expression of either TWIST1 or SNAIL induced EMT; the resultant HMECs displayed properties of breast epithelial stem cells in terms of expressing the antigen profile of $\mathrm{CD} 44^{\text {high }} \mathrm{CD} 24^{\text {low }}$, forming mammospheres, and a generating mammary gland structure in immunocompromised mice [101]. In either HER2 or HRASV12 transformed HMECs, the enforced expression of TWIST or ZEB induced breast cancer stem cells (BSCSs) [101]. The association of BCSCs with EMT was also observed in HMECs transformed with the combination of hTERT, SV40 T/t, and HRASV12 [102]. In the mouse model of KRAS and p53 for pancreatic cancer, the deletion of ZEB1 inhibited stemness and metastasis [103]. In PC, evidence suggests TWIST1 contributing to bone metastasis [104]; TWIST1 enhances PC metastasis by upregulating HOXA9 through affecting WDR5 expression and chromatin structure $[105,106]$. The upregulation of histone methyltransferase, MMSET/WHSC1, and p53 mutation induce EMT in PC through the activation of TWIST1 [107,108]. Recent developments reveal a central role of ZEB1 in promoting EMT, CSC, and metastasis [109]. It has been recently reported that the ZEB1-miR375-YAP1 pathway promotes PC metastasis via regulating EMT and MET; while ZEB1 induces EMT, miR375 initiates MET via the inhibition of YAP1 expression in PC [110]. ZEB1 was reported to collaborate with the SRC kinase to drive EMT in vitro. In human PC metastases $(n=185)$ and bone xenografts, ZEB1 and E-cadherin were both expressed at high levels, suggesting the occurrence of MET [111]. Collectively, functional and clinical investigations strongly support a critical role of partial EMT in CSC and PCSCs in the case of PC-derived metastasis.

\subsection{PCSCs in Circulating Tumor Cells (CTC) Lead to Metastasis}

Similar to the first demonstration of CSC following the transplantation of a single leukemia cell into mice in 1937 [112], circulating tumor cells have been known for 150 years since their first report in 1869 by Ashworth [113]. However, their importance in tumorigenesis has only been recently realized as a result of knowledge and technological advances. The involvement of the vascular pathways in metastatic spread and the "seed and soil" hypothesis of Stephen Paget [114] highlighted circulating tumor cells (CTC) as "seeds" or source of distant metastasis $[85,86,115]$. CTCs were particularly enriched in patients with metastatic disease of PC, breast cancer, ovarian cancer, colorectal cancer, lung cancer, and other cancers [116], and were associated with reductions in overall survival in patients with breast, colorectal, and lung cancers [117-119]. CTCs possess a significant prognostic value in diagnosis for PC metastasis [120,121]. The EpCAM cell surface marker-based CellSearch platform has been approved by the FDA (Food and Drug Administration) for prognostic diagnosis in patients with breast, prostate, and colorectal cancers [122].

In line with recently identified intratumoral heterogeneity [76,77], CTCs also consist of multiple types of cancer cells [123]. Thus, it is conceivable for the CSC population in CTCs to be metastasis-initiating cells $[124,125]$. The existence of this CTC-CSC population is supported by the identification of breast cancer CTCs undergoing EMT [99], which is a process playing a critical role in CSCs. A subpopulation of breast cancer CTCs marked with EpCAM ${ }^{+}$CD $44^{+}$CD $47^{+} \mathrm{MET}^{+}$ was enriched with metastasis-initiating capacity and associated with a reduction in overall survival (Table 2) [126]. A subgroup of CTCs from breast cancer patients with brain metastasis were isolated, cultured, and selected for brain metastasis markers EpCAM ${ }^{-} \mathrm{HER}^{+} \mathrm{EGFR}^{+} \mathrm{HPSE}^{+} \mathrm{NOTCH}^{+}$; when compared to unselected CTC lines, these CTCs were capable of forming brain and lung metastases in nude mice (Table 2) [127]. The observation that these CTCs were EpCAM ${ }^{-}$suggests that they have EMT properties. CTCs' lines with CSC propensities were also demonstrated for colorectal cancer; these CTCs were able to generate xenografts after subcutaneous injection and liver metastasis following intrasplenic injection (Table 2) [128]. In PC, EGFR ${ }^{+}$CTCs were suggested to be involved in bone metastasis [129]; EGFR mediates SOX2 expression in PCSCs [40]. CTCs with partial EMT were associated with PC metastasis; these CTCs were $\mathrm{CK}^{+}$Vimentin ${ }^{+} \mathrm{CD} 45^{-}$(Table 2) or $\mathrm{EpCAM}^{+} \mathrm{CK}^{+} \mathrm{E}$-cadherin ${ }^{+}$Vimentin ${ }^{+} \mathrm{N}$-cadherin ${ }^{+} \mathrm{O}$-cadherin ${ }^{+} \mathrm{CD}_{133^{+}}[100,130]$. Collectively, while 
definitive and directive evidence for the existence of CTC PCSC and the role of CSCs as "seeds" for distant metastasis is currently lacking, the growing evidence obtained from multiple domains nonetheless supports CTC-CSCs playing a pivotal role in distant metastasis (Table 2).

Table 2. CTCs contribute to metastasis.

\begin{tabular}{|c|c|c|c|c|}
\hline Tumor ${ }^{1}$ & $\mathrm{CTC}^{2}$ & Outcome $^{3}$ & Metastasis $^{4}$ & Ref. \\
\hline $\mathrm{BC}$ & $\mathrm{EpCAM}^{+} \mathrm{CD} 44^{+} \mathrm{CD}_{4} 7^{+} \mathrm{MET}^{+}$ & OS $^{6}$ & NSG mice; bone mets 5 & [126] \\
\hline $\mathrm{BC}$ & $\mathrm{EpCAM}^{-} \mathrm{HER}^{+} \mathrm{EGFR}^{+} \mathrm{HPSE}^{+} \mathrm{NOTCH}^{+}$ & $\mathrm{NA}^{7}$ & Nude mice; lung met ${ }^{8}$, brain met ${ }^{9}$ & [127] \\
\hline CRC & CTC lines with CSC properties & $\mathrm{NA}^{7}$ & Nude mice; lung and liver met ${ }^{10}$ & [128] \\
\hline PC & $\mathrm{CK}^{+}$Vimentin ${ }^{+} \mathrm{CD} 45^{-}$ & Met ${ }^{11}$ & $\mathrm{NA}^{7}$ & [100] \\
\hline
\end{tabular}

\subsection{Association of PCSCs with Metastasis}

Evidence reveals a relationship between CSCs and metastasis in general [131] as well as between PCSCs and PC metastasis [132]. Breast cancer CSCs isolated from primary tumors produced metastasis upon implantation into the mammary fat pad of NOD/SCID mice [133]. In colorectal cancer, CD26 ${ }^{+}$ CSCs generated liver metastases following implantation into the mouse cecal wall [134]; in pancreatic cancer, $\mathrm{CD} 133^{+} \mathrm{CXCR} 4^{+} \mathrm{CSC}$ s were responsible for metastasis [26] and the overexpression of CXCR4 enhanced the metastatic potential of pancreatic cancer cells [135]. The stromal-derived factor 1 (SDF-1)/CXCL12 and its chemokine receptor CXCR4 play a critical role in the retention or homing of hematopoietic stem cells in bone marrow [136,137], suggesting CXCR4 playing a role in "seeding" cancerous cells for metastasis. In this regard, the SDF-1/CXCR4 pathway plays a critical role in the interaction between the tumor and its microenvironment $[138,139]$. CXCR4 expression is associated with the metastasis of human non-small cell lung cancer (NSCLC) [140], and contributes to breast cancer metastasis [141]. The SDF-1/CXCR4 axis directs PC metastasis to the bone [142], which is consistent with a critical role of SDF-1/CXCR4 in bone metastasis [143]. SDF-1 in PC stromal fibroblasts can be induced through the recruitment of mesenchymal stem cells (MSCs) [144], and human PC was reported to contain cells with the properties of MSCs [145]. In hTERT-immortalized human prostate epithelial cells, $\mathrm{CD}_{133^{+}}$cells displayed stemness along with an elevation in CXCR4 expression [146]; similarly, NANOG induced CSC propensities in PC cells concurrently with the upregulation of CD133 and CXCR4 [147]. The CXCR4 ligand CXCL12 $\gamma$ was reported to induce PCSCs and thereby promote PC metastasis [148]. Taken together, accumulative evidence supports a role of CSCs in general and PCSCs in particular as "seeds" of metastasis, in part via the SDF-1/CXCR4 axis. Of note, SDF-1 is expressed at high levels in lymph nodes, lung, liver, and bone marrow, which are the common organs of metastasis [149].

Additionally, functional evidence supports a critical role of PCSCs in PC metastasis. MicroRNA-141 was reported to suppress PCSC properties of CD44 ${ }^{\text {hi }}$ PC3 and CD44 ${ }^{+}$DU145 cells and the cell's ability to generate lung metastasis in an orthotopic PC model using NOD/SCID mice; the downregulation of microRNA-141 was observed in CD44+ primary PCs [150]. Likewise, miR-34a possesses similar functions in the suppression of PCSCs and thereby PC metastasis [151].

\section{Pathways Regulating CSCs}

In addition to cancer initiation, CSCs are widely regarded to play a central role in cancer progression, particularly in metastasis and resistance to therapies; in terms of PC, evidence supports PCSCs being critical in PC metastasis (this review) and CRPC development [152]. Solid tumors are not only heterogeneous but also have extensive intratumor heterogeneity [76,77]. The proportion of cells with CSC properties increases with cancer progression [153]. In this regard, CSCs including PCSCSs are heterogeneous and regulated by complex mechanisms; at the center of these regulations is the possession of CSC s' plasticity. 


\subsection{Dynamically Maintaining CSC "Stemness"}

CSCs are commonly associated with a specific set of surface antigens, such as CD34 ${ }^{+} \mathrm{CD} 38^{-}$for $\mathrm{AML}, \mathrm{CD} 133^{+}, \mathrm{CD}_{4} 4^{+}$, and other antigens for solid tumors, based on their ability to initiate tumors in nude and NOD/SCID mice [18]. However, CSCs may not inclusively reside in cells marked by these markers. For incidence, with the NOD/SCID/IL2R $\gamma^{-/-}$(NSG) mouse line that is more receptive to xenograft formation, $\mathrm{CD} 34^{+} \mathrm{CD} 38^{+}$AML cells were also able to initiate tumors [154]. Similarly, $\mathrm{CD}_{133^{+}}$NSCLS cells were substantially more efficient at producing xenograft in NOD/SCID mice [24]; in NOD/SCID/IL2R $\gamma^{-/-}$mice, CD133 ${ }^{+}$and CD133- NSCLC cells generated xenografts at rates of $6 / 11$ and $7 / 13$, respectively [155]. While CD133 ${ }^{+}$marks brain CSCs [20], both CD133 ${ }^{+}$and CD133 ${ }^{-}$ glioblastoma cells displayed CSC properties and generated xenografts in immunocompromised mice with comparable efficiencies [156]. Human PCSCs were identified as CD44 ${ }^{+} \alpha_{2} \beta_{1}$ hi $C D 133^{+}$[31] and $\mathrm{CD}_{133^{+}}$cells isolated from 22Rv1 human PC cells were enriched with a set of CSC genes (CD44, OCT4, c-MYC, and BMI1) [157]; in a set of hTERT-immortalized human primary prostate cells, $\mathrm{CD}_{133^{+}}$and $\mathrm{CD} 133^{-}$cells comparably produced xenografts in NOD/SCID mice [158]. A difference in PCSC-associated proteins was also observed in aldehyde dehydrogenase (ALDH), which is a signature protein of CSC $[159,160]$. ALDH1A1 has been suggested to be associated with PCSCs [161-164]; a significant upregulation of ALDH3A1 in PCSCs and following PC progression was also reported [165]. In mouse models for PC, both the basal and luminal epithelial cells are able to initiate tumors (see Section 3). Intriguingly, tumors generated from human basal prostate epithelial cells were maintained through luminal cancerous cell-derived PCSCs [73]. The variations discussed above suggest communications between different populations of CSCs; alternatively, CSCs may be maintained via a dynamic manner depending on intratumoral and environmental cues (Figure 2).

a

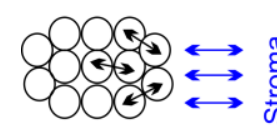

Non CSCs b

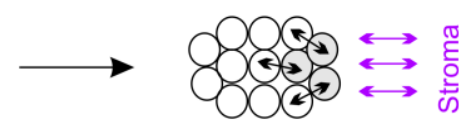

CSCs
C

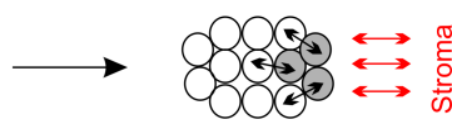

CSCs

Figure 2. A dynamic model of cancer stem cells (CSCs). Intratumoral communications (black arrows with double directions) and tumor stromal communications (colored arrows with double directions) in (a) lead to the generation of CSCs (b). These communications will also drive CSC evolution (c).

The latter model is different from the classic concept of CSCs by emphasizing CSCs as a status of regulation rather than a subpopulation of cells that are intrinsically wired. This model may explain the isolation of CSCs from numerous cancer cell lines despite having been cultured for decades in 10\% serum, which is a condition that is not supportive for CSCs. For incidence, DU145-derived spheres were 100-fold more tumorigenic in NOD/SCID mice compared to monolayer cells; in the presence of $10 \%$ serum, sphere cells proliferated significantly slower [39]. If what was preserved is in fact a CSC status instead of CSCs, this may explain the isolation of CSCs from cancer cell lines.

Intriguingly, this model of CSCs has recently gained in vivo support [166]. In a mouse model for colorectal cancer with the Lgr5 promoter driving the expression of diphtheria toxin receptor (DTR) to allow the controllable ablation of $\mathrm{Lgr5}^{+}$cells, de Sousa e Melo et al. reported that the selective ablation of $\mathrm{Lgr}^{+} \mathrm{CSC}$ with the addition of diphtheria toxin stopped tumor growth without tumor regression $[167,168]$. The removal of diphtheria toxin regenerated $\mathrm{Lgr}^{+}$CSCs and renewed tumor growth [168]. The depletion of $\mathrm{Lgr}^{+}$CSCs substantially suppressed liver metastasis [168], supporting the importance of CSCs in distant metastasis. Impressively, the diphtheria toxin-induced ablation of $\mathrm{Lgr}^{+}$CSCs in liver metastases resulted in tumor regression, and the growth of metastatic tumors was not renewed after the administration of diphtheria toxin was stopped [168]. This provides a plausible scenario to therapeutically target CSCs in colorectal cancer metastases. The research by de Sousa e Melo et al. [168] provided the first in vivo evidence suggesting that the stemness of CSCs, at least in 
primary colorectal cancer, can be acquired by dedifferentiation from cancer cells through unknown mechanisms, and the acquisition of CSCs ensures tumor growth and thus possible progression.

\subsection{Mechanisms Regulating CSC Plasticity}

CSC plasticity is regulated by complex mechanisms. External cues include interactions with stromal cells, hypoxia, and inflammation [92]. The contribution of hypoxia to CSCs is consistent with the hypoxic conditions observed for many adult SC niches [169]. Just as stem cells show properties of immune privilege [170], CSCs also possess these propensities [171]. These external factors will work through internal mechanisms or pathways for CSC regulation.

CSC plasticity is regulated by genome instability $[79,172]$. DNA damage response (DDR) is the mechanism maintaining genome stability through the coordination of checkpoint activation and DNA lesion repairs $[69,173,174]$. To ensure their physiological functions, embryonic SCs and adult SCs have a robust DDR capacity to remain their genome integrity and stability $[79,175]$. DDR is regulated by three apical kinases, ATM (ataxia telangiectasia-mutated), ATR (ataxia telangiectasia and Rad3-related), and DNA-PK (DNA-dependent protein kinase) kinases. Checkpoint activation halts cell proliferation, allowing lesions to be repaired $[69,173,174]$. The DDR process is compromised in aging stem cells, which is a likely mechanism underlying SC as an origin of cancer [79,175]. In PC, abnormalities in the ATM pathway were reported [176]. BMI1 is required for the maintenance of hematopoietic stem cells, neural stem cells [177-182], and intestinal stem cells [183,184]; BMI1 is also important in sustaining CSCs for multiple cancer types [185]. The upregulation of BMI1 occurs in PC [68]; the BMI1 ${ }^{+}$luminal cells are an origin of PC [67]. It has been recently reported that BMI1 reduces the functions of ATM and ATR during DDR, and thus contributes to genome instability [69,186-188]. In comparison to non-CSC PC cells, PCSCs display a robust DDR response to etoposide-induced double-strand DNA breaks (DSBs), which contributes to the resistance of PCSCs to DSB-associated toxicity [189]. Elevated DDR was also reported in patient-derived and cultured CSCs [79].

The ability to regenerate $\mathrm{Lgr}^{+} \mathrm{CSC}$ from other colorectal cancer cells supports epigenetics being a major mechanism regulating CSC plasticity $[168,190]$. Epigenetic regulation can affect chromatin structure via histone methylation and ubiquitination [190]. EZH2 is the enzymatic subunit of the Polycomb-repressive complex 2 and mediates the trimethylation of histone $\mathrm{H} 3$ at lysine 27 (H3K27me3) [191]. The protein has a critical function in maintaining the CSCs of glioblastoma [192]. EZH2 expression is upregulated in PCSCs, and plays an essential role in PCSC growth [193]. PCSCs are regulated by a set of non-coding RNA molecules, MicroRNA-141, miR-34a, and miR-1991-3p [150,151,194]. Signatures of miRNA have been identified in PCSC and other CSC types [195]. From DU145 PC cells, PCSCs can be isolated in serum-free medium as spheres at the rate of $1.25 \%$; when cultured in medium supplemented with $10 \%$ serum, it took 20 passages for the sphere-forming ability (which is indicative of stemness) of PCSCs to reduce to $2.2 \%$ [39], indicating the gradual loss of the PCSC-associated epigenetic pattern.

Recent developments reveal a critical role of partial EMT in regulating the lineage plasticity in multiple cancer types (see Section 4.1) [95]. Cancer cells with both epithelial and mesenchymal markers are plastic in driving distant metastasis through MET in HF-SCC [95,97,98]. In PC, macrometastasis in the lung expressed high levels of CKs and low levels of vimentin; the reverse profile of CK and vimentin was observed in micrometastasis [96], implying a contribution of partial EMT-associated plasticity in MET transition. The induction of EMT and prevention of its reversal to MET suppresses metastasis [196]. Overexpression of the paired-related homeobox transcription factor 1 (Prrx1) in Madin-Darby canine kidney (MDCK) cells induced EMT; ectopic Prrx1 expression in either MDCK or BT-549 cells prevented lung metastasis as a result of the inability of MET transition, while knockdown of the ectopically expressed Prrx1 enabled lung metastasis [196]. The intermediate metastable stage of EMT is critical in regulating trophoblast stem cells [197], supporting the important contributions of partial EMT in CSC plasticity. This concept is also supported by the partial EMT status detected in mesenchymal sarcomas [198]; this is because as a tumor with the mesenchymal origin, sarcomas may 
not need partial EMT to enhance its motility and invasion. In accordance with partial EMT regulating CSC plasticity, this EMT status likely contributes to the aggressiveness of sarcomas [198].

\subsection{Molecular Basis of CSC Stemness and Plasticity}

The current CSC model emphasizes the central importance of CSCs in cancer initiation and evolution. Thus, it remains critical to understand the molecular basis of reprogramming non-CSCs toward CSC. While current knowledge in this field remains limited, recent developments have shed light on this concept.

In PC, the inhibition of AR promotes PCSCs [199]. NANOG is a critical pluripotency reprogramming factor [200] that contributes to PCSCs [152]. Mutations in the Speckie-type POZ protein (SPOP) gene identify a subtype of human PC [201,202]; SPOP facilitates the homologous recombination repair of DSBs [203]; SPOP mutations are enriched with genomic alterations in the IQGAP2 tumor suppressor gene in PC [204]. In line with these observations, SPOP was recently reported to suppress PCSCs through the degradation of NANOG $[205,206]$. Additionally, the signalings of Wnt, Sonic Hedgehog, Notch, Cav-1, and others in regulating PCSCs have been recently reviewed [207].

Genomic sequencing revealed a prevalence of mutations in TP53 (53.3\%) and PTEN (40.7\%) in mCRPCs [208], suggesting an important interaction between these two tumor suppressors in suppressing the acquisition of a PCSC-like stage and/or the induction of the lineage plasticity of PCSCs during the progression of metastasis and CRPC. This concept is supported by the observations that PCs with the inactivation of both tumor suppressors are resistant to abiraterone and progress to neuroendocrine (NE) PC following abiraterone treatment in both mouse model and patients [209]. Loss of the TP53 and RB1 tumor suppressor genes are part of a signature event in NEPC development following anti-androgen treatment [210]. While PCs in prostate-specific $P T E N^{-/-}$mice are not generally metastatic, the co-knockout of $R B 1$ resulted in highly efficient $(100 \%)$ metastasis to the lymph node, lung, and liver as well as bone (2/10) [211]. Triple knockout of PTEN, RB1, and TP53 substantially enhanced NEPC progression following castration; the gene expression profile of these mouse NEPCs shares a similar profile with human NEPCs [211]. These observations are consistent with the association of the triple tumor suppressors with PC plasticity [212,213]. Furthermore, the NEPC lineage plasticity was also resulted from human primary prostate epithelial cells when engineered with AKT activation, RB1 knockdown, the expression of dominant-negative p53, MYC, and BCL2 [214]. Collectively, these new developments reveal a critical role of the tumor suppressor genes TP53 and RB1 in suppressing PCSC reprogramming. This process resembles the induction of iPSCs (inducible pluripotent stem cells), which is associated with DNA damage and the inhibition of p53 facilitates reprogramming toward iPSC [215].

The co-inactivation of PTEN, RB1, and TP53 upregulates SOX2 and EZH2 [211]. Through H3K27me3, EZH2 suppresses AR expression, which facilitates the reprogramming of PC to PCSCs [211]. Deficiencies in TP53 and RB1 induce lineage plasticity, which allows a switch from AR-dependent luminal cancer to AR-independent basal-like cancer following anti-androgen enzalutamide treatments [216]. This lineage switch is mediated by SOX2; the loss of TP53 and RB1 upregulate SOX2; the inhibition of SOX2 suppresses the lineage switch [216]. SOX2 was also reported to be responsible for a luminal-to-basal lineage switch in PCs produced by mouse $\mathrm{BMI}^{+}$luminal cells with PTEN ${ }^{-/-}$following castration $[67,217]$. Taken together, the evidence indicates an important contribution of SOX2 in the epigenetic reprogramming of PC cells toward PCSCs in response to anti-androgen therapies (Figure 3). 


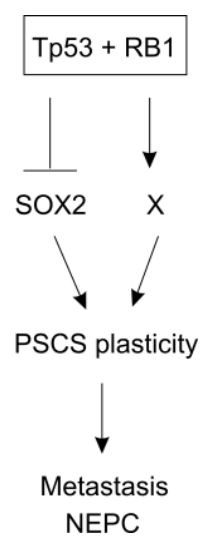

Figure 3. Current evidence reveals a critical role of TP53 together with RB1 in the suppression of SOX2 expression and affecting other events (X). SOX2 and X confer the cell plasticity of PCSCs, which promotes PC metastasis and induces neuroendocrine PC (NEPC) in response to anti-androgen therapies.

\section{Conclusions}

Overwhelming evidence supports the central role of CSCs in general and PCSCs in particular in cancer initiation, progression, and resistance to therapies. However, even with this optimistic opinion, direct evidence is lacking. In mouse PC models, lineage tracing with PTEN knockout as the oncogenic signal indicated PCSC as an origin of PC (Section 3), and suggested partial EMT as a factor inducing metastasis (Section 4); the inactivation of PTEN with the concurrent inactivation of TP53 and RB1 contributed to lineage plasticity leading to PCSCs (Section 5.3). A critical question is to what extent is this knowledge applicable to PC initiation and metastasis in patients? Is the occurrence of these oncogenic drivers the primary cause of PC or the outcomes of genome instability following PC tumorigenesis? In the latter scenario, these oncogenic drivers would be expected to promote rather than initiate PC. Nevertheless, accumulating evidence demonstrates the importance of PCSCs in PC tumorigenesis, both in initiation and progression.

It is an emerging concept that CSCs are a property of cancer instead of a specific group of cells that are intrinsically wired to be CSCs [168]. This discovery is generally consistent with our understanding of cancer being plastic, i.e., cancers evolve in response to toxicity caused by therapies. This observation suggests that targeting CSCs themselves might not be the perfect strategy, as these cells may not exist, and can be replenished upon environmental cues; instead, disrupting the pathways or targeting stromal events leading to the acquisition of lineage plasticity of CSCs could be more effective in controlling cancer growth and metastasis. The development of partial EMT in conferring lineage plasticity, particularly in CTCs, calls for modification regarding using EpCAM as the sole surface marker. In this regard, the use of EpCAM together with other mesenchymal markers should be explored.

Author Contributions: Conceptualization, W.M., X.L., A.K. and D.T.; material preparation, W.M., X.L., Y.G., and K.Z.; writing—original draft preparation, W.M. and D.T.; writing-review, all authors; writing editing-Y.G. and D.T.; supervision, D.T.

Funding: D.T. is supported by grants from Cancer Research Society and Canadian Cancer Society (grant \#: 319412) and by funds from Hamilton Urologic Oncology Research Center (HUORC). Y.G. is supported by Studentship provided by Ontario Graduate Scholarships and Research Institute of St Joe's Hamilton.

Conflicts of Interest: The authors declare no conflict of interest. 


\section{References}

1. Siegel, R.; Ward, E.; Brawley, O.; Jemal, A. Cancer statistics, 2011: The impact of eliminating socioeconomic and racial disparities on premature cancer deaths. CA Cancer J. Clin. 2011, 61, 212-236. [CrossRef] [PubMed]

2. Shen, M.M.; Abate-Shen, C. Molecular genetics of prostate cancer: New prospects for old challenges. Genes Dev. 2010, 24, 1967-2000. [CrossRef]

3. Isaacs, J.T.; Coffey, D.S. Etiology and disease process of benign prostatic hyperplasia. Prostate. Suppl. 1989, 2, 33-50. [CrossRef]

4. Lytton, B. Prostate cancer: A brief history and the discovery of hormonal ablation treatment. J. Urol. 2001, 165, 1859-1862. [CrossRef]

5. Wong, Y.N.; Ferraldeschi, R.; Attard, G.; de Bono, J. Evolution of androgen receptor targeted therapy for advanced prostate cancer. Nat. Rev. Clin. Oncol. 2014, 11, 365-376. [CrossRef]

6. Skvortsov, S.; Skvortsova, I.I.; Tang, D.G.; Dubrovska, A. Concise review: Prostate cancer stem cells: Current understanding. Stem Cells 2018, 36, 1457-1474. [CrossRef]

7. Ross, J.S. The androgen receptor in prostate cancer: Therapy target in search of an integrated diagnostic test. Adv. Anat. Pathol. 2007, 14, 353-357. [CrossRef]

8. Moon, C.; Park, J.C.; Chae, Y.K.; Yun, J.H.; Kim, S. Current status of experimental therapeutics for prostate cancer. Cancer Lett. 2008, 266, 116-134. [CrossRef] [PubMed]

9. Bagnall, P. Diagnosis and treatment of prostate cancer. Nurs. Times 2014, 110, 12-15. [PubMed]

10. Heinlein, C.A.; Chang, C. Androgen receptor in prostate cancer. Endocr. Rev. 2004, 25, 276-308. [CrossRef]

11. Tannock, I.F.; de Wit, R.; Berry, W.R.; Horti, J.; Pluzanska, A.; Chi, K.N.; Oudard, S.; Theodore, C.; James, N.D.; Turesson, I.; et al. Docetaxel plus prednisone or mitoxantrone plus prednisone for advanced prostate cancer. N. Engl. J. Med. 2004, 351, 1502-1512. [CrossRef]

12. Berthold, D.R.; Pond, G.R.; Soban, F.; de Wit, R.; Eisenberger, M.; Tannock, I.F. Docetaxel plus prednisone or mitoxantrone plus prednisone for advanced prostate cancer: Updated survival in the tax 327 study. J. Clin. Oncol. 2008, 26, 242-245. [CrossRef]

13. De Bono, J.S.; Logothetis, C.J.; Molina, A.; Fizazi, K.; North, S.; Chu, L.; Chi, K.N.; Jones, R.J.; Goodman, O.B., Jr.; Saad, F.; et al. Abiraterone and increased survival in metastatic prostate cancer. N. Engl. J. Med. 2011, 364, 1995-2005. [CrossRef] [PubMed]

14. Scher, H.I.; Fizazi, K.; Saad, F.; Taplin, M.E.; Sternberg, C.N.; Miller, K.; de Wit, R.; Mulders, P.; Chi, K.N.; Shore, N.D.; et al. Increased survival with enzalutamide in prostate cancer after chemotherapy. N. Engl. J. Med. 2012, 367, 1187-1197. [CrossRef]

15. Al-Hajj, M.; Wicha, M.S.; Benito-Hernandez, A.; Morrison, S.J.; Clarke, M.F. Prospective identification of tumorigenic breast cancer cells. Proc. Natl. Acad. Sci. USA 2003, 100, 3983-3988. [CrossRef]

16. Lapidot, T.; Sirard, C.; Vormoor, J.; Murdoch, B.; Hoang, T.; Caceres-Cortes, J.; Minden, M.; Paterson, B.; Caligiuri, M.A.; Dick, J.E. A cell initiating human acute myeloid leukaemia after transplantation into scid mice. Nature 1994, 367, 645-648. [CrossRef]

17. Baccelli, I.; Trumpp, A. The evolving concept of cancer and metastasis stem cells. J. Cell Biol. 2012, 198, 281-293. [CrossRef]

18. Kreso, A.; Dick, J.E. Evolution of the cancer stem cell model. Cell Stem Cell 2014, 14, 275-291. [CrossRef]

19. She, J.J.; Zhang, P.G.; Wang, Z.M.; Gan, W.M.; Che, X.M. Identification of side population cells from bladder cancer cells by dyecycle violet staining. Cancer Biol. Ther. 2008, 7, 1663-1668. [CrossRef]

20. Singh, S.K.; Hawkins, C.; Clarke, I.D.; Squire, J.A.; Bayani, J.; Hide, T.; Henkelman, R.M.; Cusimano, M.D.; Dirks, P.B. Identification of human brain tumour initiating cells. Nature 2004, 432, 396-401. [CrossRef]

21. Ovalle, S.; Gutierrez-Lopez, M.D.; Olmo, N.; Turnay, J.; Lizarbe, M.A.; Majano, P.; Molina-Jimenez, F.; Lopez-Cabrera, M.; Yanez-Mo, M.; Sanchez-Madrid, F.; et al. The tetraspanin CD9 inhibits the proliferation and tumorigenicity of human colon carcinoma cells. Int. J. Cancer 2007, 121, 2140-2152. [CrossRef] [PubMed]

22. Ricci-Vitiani, L.; Lombardi, D.G.; Pilozzi, E.; Biffoni, M.; Todaro, M.; Peschle, C.; De Maria, R. Identification and expansion of human colon-cancer-initiating cells. Nature 2007, 445, 111-115. [CrossRef] [PubMed]

23. Prince, M.E.; Sivanandan, R.; Kaczorowski, A.; Wolf, G.T.; Kaplan, M.J.; Dalerba, P.; Weissman, I.L.; Clarke, M.F.; Ailles, L.E. Identification of a subpopulation of cells with cancer stem cell properties in head and neck squamous cell carcinoma. Proc. Natl. Acad. Sci. USA 2007, 104, 973-978. [CrossRef] 
24. Eramo, A.; Lotti, F.; Sette, G.; Pilozzi, E.; Biffoni, M.; Di Virgilio, A.; Conticello, C.; Ruco, L.; Peschle, C.; De Maria, R. Identification and expansion of the tumorigenic lung cancer stem cell population. Cell Death Differ. 2008, 15, 504-514. [CrossRef]

25. Fang, D.; Nguyen, T.K.; Leishear, K.; Finko, R.; Kulp, A.N.; Hotz, S.; Van Belle, P.A.; Xu, X.; Elder, D.E.; Herlyn, M. A tumorigenic subpopulation with stem cell properties in melanomas. Cancer Res. 2005, 65, 9328-9337. [CrossRef] [PubMed]

26. Hermann, P.C.; Huber, S.L.; Herrler, T.; Aicher, A.; Ellwart, J.W.; Guba, M.; Bruns, C.J.; Heeschen, C. Distinct populations of cancer stem cells determine tumor growth and metastatic activity in human pancreatic cancer. Cell Stem Cell 2007, 1, 313-323. [CrossRef]

27. Li, C.; Heidt, D.G.; Dalerba, P.; Burant, C.F.; Zhang, L.; Adsay, V.; Wicha, M.; Clarke, M.F.; Simeone, D.M. Identification of pancreatic cancer stem cells. Cancer Res. 2007, 67, 1030-1037. [CrossRef]

28. Wu, C.; Wei, Q.; Utomo, V.; Nadesan, P.; Whetstone, H.; Kandel, R.; Wunder, J.S.; Alman, B.A. Side population cells isolated from mesenchymal neoplasms have tumor initiating potential. Cancer Res. 2007, 67, 8216-8222. [CrossRef] [PubMed]

29. Visvader, J.E.; Lindeman, G.J. Cancer stem cells in solid tumours: Accumulating evidence and unresolved questions. Nat. Rev. Cancer 2008, 8, 755-768. [CrossRef]

30. Richardson, G.D.; Robson, C.N.; Lang, S.H.; Neal, D.E.; Maitland, N.J.; Collins, A.T. Cd133, a novel marker for human prostatic epithelial stem cells. J. Cell Sci. 2004, 117, 3539-3545. [CrossRef]

31. Collins, A.T.; Berry, P.A.; Hyde, C.; Stower, M.J.; Maitland, N.J. Prospective identification of tumorigenic prostate cancer stem cells. Cancer Res. 2005, 65, 10946-10951. [CrossRef] [PubMed]

32. Huss, W.J.; Gray, D.R.; Greenberg, N.M.; Mohler, J.L.; Smith, G.J. Breast cancer resistance protein-mediated efflux of androgen in putative benign and malignant prostate stem cells. Cancer Res. 2005, 65, 6640-6650. [CrossRef] [PubMed]

33. Goldstein, A.S.; Lawson, D.A.; Cheng, D.; Sun, W.; Garraway, I.P.; Witte, O.N. Trop2 identifies a subpopulation of murine and human prostate basal cells with stem cell characteristics. Proc. Natl. Acad. Sci. USA 2008, 105, 20882-20887. [CrossRef] [PubMed]

34. Jiao, J.; Hindoyan, A.; Wang, S.; Tran, L.M.; Goldstein, A.S.; Lawson, D.; Chen, D.; Li, Y.; Guo, C.; Zhang, B.; et al. Identification of CD166 as a surface marker for enriching prostate stem/progenitor and cancer initiating cells. PLoS ONE 2012, 7, e42564. [CrossRef] [PubMed]

35. Chen, X.; Li, Q.; Liu, X.; Liu, C.; Liu, R.; Rycaj, K.; Zhang, D.; Liu, B.; Jeter, C.; Calhoun-Davis, T.; et al. Defining a population of stem-like human prostate cancer cells that can generate and propagate castration-resistant prostate cancer. Clin. Cancer Res. 2016, 22, 4505-4516. [CrossRef] [PubMed]

36. Qin, J.; Liu, X.; Laffin, B.; Chen, X.; Choy, G.; Jeter, C.R.; Calhoun-Davis, T.; Li, H.; Palapattu, G.S.; Pang, S.; et al. The psa(-/lo) prostate cancer cell population harbors self-renewing long-term tumor-propagating cells that resist castration. Cell Stem Cell 2012, 10, 556-569. [CrossRef]

37. Patrawala, L.; Calhoun, T.; Schneider-Broussard, R.; Li, H.; Bhatia, B.; Tang, S.; Reilly, J.G.; Chandra, D.; Zhou, J.; Claypool, K.; et al. Highly purified CD44+ prostate cancer cells from xenograft human tumors are enriched in tumorigenic and metastatic progenitor cells. Oncogene 2006, 25, 1696-1708. [CrossRef] [PubMed]

38. Rybak, A.P.; Ingram, A.J.; Tang, D. Propagation of human prostate cancer stem-like cells occurs through egfr-mediated erk activation. PLoS ONE 2013, 8, e61716. [CrossRef]

39. Rybak, A.P.; He, L.; Kapoor, A.; Cutz, J.C.; Tang, D. Characterization of sphere-propagating cells with stem-like properties from DU145 prostate cancer cells. Biochim. Biophys. Acta 2011, 1813, 683-694. [CrossRef] [PubMed]

40. Rybak, A.P.; Tang, D. SOX2 plays a critical role in egfr-mediated self-renewal of human prostate cancer stem-like cells. Cell. Signal. 2013, 25, 2734-2742. [CrossRef]

41. Garraway, I.P.; Sun, W.; Tran, C.P.; Perner, S.; Zhang, B.; Goldstein, A.S.; Hahm, S.A.; Haider, M.; Head, C.S.; Reiter, R.E.; et al. Human prostate sphere-forming cells represent a subset of basal epithelial cells capable of glandular regeneration in vivo. Prostate 2010, 70, 491-501. [CrossRef] [PubMed]

42. Bonnet, D.; Dick, J.E. Human acute myeloid leukemia is organized as a hierarchy that originates from a primitive hematopoietic cell. Nat. Med. 1997, 3, 730-737. [CrossRef]

43. Rautenberg, C.; Germing, U.; Haas, R.; Kobbe, G.; Schroeder, T. Relapse of acute myeloid leukemia after allogeneic stem cell transplantation: Prevention, detection, and treatment. Int. J. Mol. Sci. 2019, 20, 228. [CrossRef] 
44. Wojno, K.J.; Epstein, J.I. The utility of basal cell-specific anti-cytokeratin antibody (34 beta e12) in the diagnosis of prostate cancer. A review of 228 cases. Am. J. Surg. Pathol. 1995, 19, 251-260. [CrossRef]

45. Shah, R.B.; Zhou, M.; LeBlanc, M.; Snyder, M.; Rubin, M.A. Comparison of the basal cell-specific markers, 34betae12 and p63, in the diagnosis of prostate cancer. Am. J. Surg. Pathol. 2002, 26, 1161-1168. [CrossRef]

46. Grisanzio, C.; Signoretti, S. P63 in prostate biology and pathology. J. Cell Biochem. 2008, 103, $1354-1368$. [CrossRef]

47. Humphrey, P.A. Diagnosis of adenocarcinoma in prostate needle biopsy tissue. J. Clin. Pathol. 2007, 60, 35-42. [CrossRef] [PubMed]

48. Okada, H.; Tsubura, A.; Okamura, A.; Senzaki, H.; Naka, Y.; Komatz, Y.; Morii, S. Keratin profiles in normal/hyperplastic prostates and prostate carcinoma. Virchows Archiv. Apathol. Anat. Histopathol. 1992, 421, 157-161. [CrossRef]

49. Parsons, J.K.; Gage, W.R.; Nelson, W.G.; De Marzo, A.M. P63 protein expression is rare in prostate adenocarcinoma: Implications for cancer diagnosis and carcinogenesis. Urology 2001, 58, 619-624. [CrossRef]

50. Goldstein, A.S.; Huang, J.; Guo, C.; Garraway, I.P.; Witte, O.N. Identification of a cell of origin for human prostate cancer. Science 2010, 329, 568-571. [CrossRef] [PubMed]

51. Lawson, D.A.; Xin, L.; Lukacs, R.U.; Cheng, D.; Witte, O.N. Isolation and functional characterization of murine prostate stem cells. Proc. Natl. Acad. Sci. USA 2007, 104, 181-186. [CrossRef] [PubMed]

52. Burger, P.E.; Xiong, X.; Coetzee, S.; Salm, S.N.; Moscatelli, D.; Goto, K.; Wilson, E.L. Sca-1 expression identifies stem cells in the proximal region of prostatic ducts with high capacity to reconstitute prostatic tissue. Proc. Natl. Acad. Sci. USA 2005, 102, 7180-7185. [CrossRef] [PubMed]

53. Leong, K.G.; Wang, B.E.; Johnson, L.; Gao, W.Q. Generation of a prostate from a single adult stem cell. Nature 2008, 456, 804-808. [CrossRef]

54. Xin, L.; Lawson, D.A.; Witte, O.N. The sca-1 cell surface marker enriches for a prostate-regenerating cell subpopulation that can initiate prostate tumorigenesis. Proc. Natl. Acad. Sci. USA 2005, 102, 6942-6947. [CrossRef]

55. Lawson, D.A.; Zong, Y.; Memarzadeh, S.; Xin, L.; Huang, J.; Witte, O.N. Basal epithelial stem cells are efficient targets for prostate cancer initiation. Proc. Natl. Acad. Sci. USA 2010, 107, 2610-2615. [CrossRef]

56. Mulholland, D.J.; Xin, L.; Morim, A.; Lawson, D.; Witte, O.; Wu, H. Lin-sca-1+cd49fhigh stem/progenitors are tumor-initiating cells in the pten-null prostate cancer model. Cancer Res. 2009, 69, 8555-8562. [CrossRef]

57. Wang, S.; Garcia, A.J.; Wu, M.; Lawson, D.A.; Witte, O.N.; Wu, H. Pten deletion leads to the expansion of a prostatic stem/progenitor cell subpopulation and tumor initiation. Proc. Natl. Acad. Sci. USA 2006, 103, 1480-1485. [CrossRef]

58. Kwon, O.J.; Xin, L. Prostate epithelial stem and progenitor cells. Am. J. Clin. Exp. Urol. 2014, 2, $209-218$.

59. Ousset, M.; Van Keymeulen, A.; Bouvencourt, G.; Sharma, N.; Achouri, Y.; Simons, B.D.; Blanpain, C. Multipotent and unipotent progenitors contribute to prostate postnatal development. Nat. Cell Biol. 2012, 14, 1131-1138. [CrossRef] [PubMed]

60. Wang, Z.A.; Mitrofanova, A.; Bergren, S.K.; Abate-Shen, C.; Cardiff, R.D.; Califano, A.; Shen, M.M. Lineage analysis of basal epithelial cells reveals their unexpected plasticity and supports a cell-of-origin model for prostate cancer heterogeneity. Nat. Cell Biol. 2013, 15, 274-283. [CrossRef] [PubMed]

61. Lu, T.L.; Huang, Y.F.; You, L.R.; Chao, N.C.; Su, F.Y.; Chang, J.L.; Chen, C.M. Conditionally ablated pten in prostate basal cells promotes basal-to-luminal differentiation and causes invasive prostate cancer in mice. Am. J. Pathol. 2013, 182, 975-991. [CrossRef]

62. Chua, C.W.; Shibata, M.; Lei, M.; Toivanen, R.; Barlow, L.J.; Bergren, S.K.; Badani, K.K.; McKiernan, J.M.; Benson, M.C.; Hibshoosh, H.; et al. Single luminal epithelial progenitors can generate prostate organoids in culture. Nat. Cell Biol. 2014, 16, 951-961. [CrossRef]

63. Choi, N.; Zhang, B.; Zhang, L.; Ittmann, M.; Xin, L. Adult murine prostate basal and luminal cells are self-sustained lineages that can both serve as targets for prostate cancer initiation. Cancer Cell 2012, 21, 253-265. [CrossRef]

64. Wang, Z.A.; Toivanen, R.; Bergren, S.K.; Chambon, P.; Shen, M.M. Luminal cells are favored as the cell of origin for prostate cancer. Cell Rep. 2014, 8, 1339-1346. [CrossRef]

65. Wang, X.; Kruithof-de Julio, M.; Economides, K.D.; Walker, D.; Yu, H.; Halili, M.V.; Hu, Y.P.; Price, S.M.; Abate-Shen, C.; Shen, M.M. A luminal epithelial stem cell that is a cell of origin for prostate cancer. Nature 2009, 461, 495-500. [CrossRef] 
66. Yoo, Y.A.; Roh, M.; Naseem, A.F.; Lysy, B.; Desouki, M.M.; Unno, K.; Abdulkadir, S.A. Bmi1 marks distinct castration-resistant luminal progenitor cells competent for prostate regeneration and tumour initiation. Nat. Commun. 2016, 7, 12943. [CrossRef]

67. Yoo, Y.A.; Vatapalli, R.; Lysy, B.; Mok, H.; Desouki, M.M.; Abdulkadir, S.A. The role of castration-resistant Bmi1+ Sox2+ cells in driving recurrence in prostate cancer. J. Natl. Cancer Inst. 2019, 111, 311-321. [CrossRef]

68. Fan, C.; He, L.; Kapoor, A.; Gillis, A.; Rybak, A.P.; Cutz, J.C.; Tang, D. Bmi1 promotes prostate tumorigenesis via inhibiting p16(INK4A) and p14(ARF) expression. Biochim. Biophys. Acta 2008, 1782, 642-648. [CrossRef]

69. Lin, X.; Ojo, D.; Wei, F.; Wong, N.; Gu, Y.; Tang, D. A novel aspect of tumorigenesis-bmi1 functions in regulating DNA damage response. Biomolecules 2015, 5, 3396-3415. [CrossRef]

70. Jia, X.; Li, X.; Xu, Y.; Zhang, S.; Mou, W.; Liu, Y.; Liu, Y.; Lv, D.; Liu, C.H.; Tan, X.; et al. Sox2 promotes tumorigenesis and increases the anti-apoptotic property of human prostate cancer cell. J. Mol. Cell Biol. 2011, 3, 230-238. [CrossRef]

71. Sattler, H.P.; Lensch, R.; Rohde, V.; Zimmer, E.; Meese, E.; Bonkhoff, H.; Retz, M.; Zwergel, T.; Bex, A.; Stoeckle, M.; et al. Novel amplification unit at chromosome 3q25-q27 in human prostate cancer. Prostate 2000, 45, 207-215. [CrossRef]

72. Barros-Silva, J.D.; Linn, D.E.; Steiner, I.; Guo, G.; Ali, A.; Pakula, H.; Ashton, G.; Peset, I.; Brown, M.; Clarke, N.W.; et al. Single-cell analysis identifies ly6d as a marker linking castration-resistant prostate luminal cells to prostate progenitors and cancer. Cell Rep. 2018, 25, 3504-3518 e3506. [CrossRef]

73. Stoyanova, T.; Cooper, A.R.; Drake, J.M.; Liu, X.; Armstrong, A.J.; Pienta, K.J.; Zhang, H.; Kohn, D.B.; Huang, J.; Witte, O.N.; et al. Prostate cancer originating in basal cells progresses to adenocarcinoma propagated by luminal-like cells. Proc. Natl. Acad. Sci. USA 2013, 110, 20111-20116. [CrossRef]

74. Dekoninck, S.; Blanpain, C. Stem cell dynamics, migration and plasticity during wound healing. Nat. Cell Biol. 2019, 21, 18-24. [CrossRef]

75. Gupta, P.B.; Pastushenko, I.; Skibinski, A.; Blanpain, C.; Kuperwasser, C. Phenotypic plasticity: Driver of cancer initiation, progression, and therapy resistance. Cell Stem Cell 2019, 24, 65-78. [CrossRef]

76. McGranahan, N.; Swanton, C. Clonal heterogeneity and tumor evolution: Past, present, and the future. Cell 2017, 168, 613-628. [CrossRef]

77. Gupta, R.G.; Somer, R.A. Intratumor heterogeneity: Novel approaches for resolving genomic architecture and clonal evolution. Mol. Cancer Res. 2017, 15, 1127-1137. [CrossRef]

78. Kreso, A.; O’Brien, C.A.; van Galen, P.; Gan, O.I.; Notta, F.; Brown, A.M.; Ng, K.; Ma, J.; Wienholds, E.; Dunant, C.; et al. Variable clonal repopulation dynamics influence chemotherapy response in colorectal cancer. Science 2013, 339, 543-548. [CrossRef]

79. Vitale, I.; Manic, G.; De Maria, R.; Kroemer, G.; Galluzzi, L. DNA damage in stem cells. Mol. Cell 2017, 66, 306-319. [CrossRef]

80. Visvader, J.E.; Clevers, H. Tissue-specific designs of stem cell hierarchies. Nat. Cell Biol. 2016, 18, 349-355. [CrossRef]

81. Chen, J.; Li, Y.; Yu, T.S.; McKay, R.M.; Burns, D.K.; Kernie, S.G.; Parada, L.F. A restricted cell population propagates glioblastoma growth after chemotherapy. Nature 2012, 488, 522-526. [CrossRef]

82. Weigelt, B.; Peterse, J.L.; van't Veer, L.J. Breast cancer metastasis: Markers and models. Nat. Rev. Cancer 2005, 5, 591-602. [CrossRef]

83. Gupta, G.P.; Massague, J. Cancer metastasis: Building a framework. Cell 2006, 127, 679-695. [CrossRef]

84. Luzzi, K.J.; MacDonald, I.C.; Schmidt, E.E.; Kerkvliet, N.; Morris, V.L.; Chambers, A.F.; Groom, A.C. Multistep nature of metastatic inefficiency: Dormancy of solitary cells after successful extravasation and limited survival of early micrometastases. Am. J. Pathol. 1998, 153, 865-873. [CrossRef]

85. Chambers, A.F.; Groom, A.C.; MacDonald, I.C. Dissemination and growth of cancer cells in metastatic sites. Nat. Rev. Cancer 2002, 2, 563-572. [CrossRef]

86. Chiang, A.C.; Massague, J. Molecular basis of metastasis. N. Engl. J. Med. 2008, 359, 2814-2823. [CrossRef]

87. De Craene, B.; Berx, G. Regulatory networks defining emt during cancer initiation and progression. Nat. Rev. Cancer 2013, 13, 97-110. [CrossRef]

88. Tsai, J.H.; Yang, J. Epithelial-mesenchymal plasticity in carcinoma metastasis. Genes Dev. 2013, 27, $2192-2206$. [CrossRef]

89. Yao, D.; Dai, C.; Peng, S. Mechanism of the mesenchymal-epithelial transition and its relationship with metastatic tumor formation. Mol. Cancer Res. 2011, 9, 1608-1620. [CrossRef] 
90. Gunasinghe, N.P.; Wells, A.; Thompson, E.W.; Hugo, H.J. Mesenchymal-epithelial transition (met) as a mechanism for metastatic colonisation in breast cancer. Cancer Metastasis Rev 2012, 31, 469-478. [CrossRef]

91. Oskarsson, T.; Batlle, E.; Massague, J. Metastatic stem cells: Sources, niches, and vital pathways. Cell Stem Cell 2014, 14, 306-321. [CrossRef] [PubMed]

92. Nassar, D.; Blanpain, C. Cancer stem cells: Basic concepts and therapeutic implications. Annu. Rev. Pathol. 2016, 11, 47-76. [CrossRef]

93. Shibue, T.; Weinberg, R.A. Emt, cscs, and drug resistance: The mechanistic link and clinical implications. Nat. Rev. Clin. Oncol. 2017, 14, 611-629. [CrossRef] [PubMed]

94. Rhim, A.D.; Mirek, E.T.; Aiello, N.M.; Maitra, A.; Bailey, J.M.; McAllister, F.; Reichert, M.; Beatty, G.L.; Rustgi, A.K.; Vonderheide, R.H.; et al. Emt and dissemination precede pancreatic tumor formation. Cell 2012, 148, 349-361. [CrossRef]

95. Pastushenko, I.; Blanpain, C. Emt transition states during tumor progression and metastasis. Trends Cell Biol. 2018. [CrossRef]

96. Ruscetti, M.; Quach, B.; Dadashian, E.L.; Mulholland, D.J.; Wu, H. Tracking and functional characterization of epithelial-mesenchymal transition and mesenchymal tumor cells during prostate cancer metastasis. Cancer Res. 2015, 75, 2749-2759. [CrossRef]

97. Latil, M.; Nassar, D.; Beck, B.; Boumahdi, S.; Wang, L.; Brisebarre, A.; Dubois, C.; Nkusi, E.; Lenglez, S.; Checinska, A.; et al. Cell-type-specific chromatin states differentially prime squamous cell carcinoma tumor-initiating cells for epithelial to mesenchymal transition. Cell Stem Cell 2017, 20, 191-204.e5. [CrossRef] [PubMed]

98. Pastushenko, I.; Brisebarre, A.; Sifrim, A.; Fioramonti, M.; Revenco, T.; Boumahdi, S.; Van Keymeulen, A.; Brown, D.; Moers, V.; Lemaire, S.; et al. Identification of the tumour transition states occurring during emt. Nature 2018, 556, 463-468. [CrossRef] [PubMed]

99. Yu, M.; Bardia, A.; Wittner, B.S.; Stott, S.L.; Smas, M.E.; Ting, D.T.; Isakoff, S.J.; Ciciliano, J.C.; Wells, M.N.; Shah, A.M.; et al. Circulating breast tumor cells exhibit dynamic changes in epithelial and mesenchymal composition. Science 2013, 339, 580-584. [CrossRef]

100. Xu, L.; Mao, X.; Guo, T.; Chan, P.Y.; Shaw, G.; Hines, J.; Stankiewicz, E.; Wang, Y.; Oliver, R.T.D.; Ahmad, A.S.; et al. The novel association of circulating tumor cells and circulating megakaryocytes with prostate cancer prognosis. Clin. Cancer Res. 2017, 23, 5112-5122. [CrossRef] [PubMed]

101. Mani, S.A.; Guo, W.; Liao, M.J.; Eaton, E.N.; Ayyanan, A.; Zhou, A.Y.; Brooks, M.; Reinhard, F.; Zhang, C.C.; Shipitsin, M.; et al. The epithelial-mesenchymal transition generates cells with properties of stem cells. Cell 2008, 133, 704-715. [CrossRef]

102. Morel, A.P.; Lievre, M.; Thomas, C.; Hinkal, G.; Ansieau, S.; Puisieux, A. Generation of breast cancer stem cells through epithelial-mesenchymal transition. PLoS ONE 2008, 3, e2888. [CrossRef]

103. Krebs, A.M.; Mitschke, J.; Lasierra Losada, M.; Schmalhofer, O.; Boerries, M.; Busch, H.; Boettcher, M.; Mougiakakos, D.; Reichardt, W.; Bronsert, P.; et al. The emt-activator zeb1 is a key factor for cell plasticity and promotes metastasis in pancreatic cancer. Nat. Cell Biol. 2017, 19, 518-529. [CrossRef]

104. Chang, Y.S.; Chen, W.Y.; Yin, J.J.; Sheppard-Tillman, H.; Huang, J.; Liu, Y.N. Egf receptor promotes prostate cancer bone metastasis by downregulating mir-1 and activating twist1. Cancer Res. 2015, 75, 3077-3086. [CrossRef]

105. Malek, R.; Gajula, R.P.; Williams, R.D.; Nghiem, B.; Simons, B.W.; Nugent, K.; Wang, H.; Taparra, K.; Lemtiri-Chlieh, G.; Yoon, A.R.; et al. Twist1-wdr5-hottip regulates hoxa9 chromatin to facilitate prostate cancer metastasis. Cancer Res. 2017, 77, 3181-3193. [CrossRef] [PubMed]

106. Gajula, R.P.; Chettiar, S.T.; Williams, R.D.; Thiyagarajan, S.; Kato, Y.; Aziz, K.; Wang, R.; Gandhi, N.; Wild, A.T.; Vesuna, F.; et al. The twist box domain is required for twist1-induced prostate cancer metastasis. Mol. Cancer Res. 2013, 11, 1387-1400. [CrossRef]

107. Ezponda, T.; Popovic, R.; Shah, M.Y.; Martinez-Garcia, E.; Zheng, Y.; Min, D.J.; Will, C.; Neri, A.; Kelleher, N.L.; Yu, J.; et al. The histone methyltransferase mmset/whsc1 activates twist1 to promote an epithelial-mesenchymal transition and invasive properties of prostate cancer. Oncogene 2013, 32, 2882-2890. [CrossRef] [PubMed] 
108. Kogan-Sakin, I.; Tabach, Y.; Buganim, Y.; Molchadsky, A.; Solomon, H.; Madar, S.; Kamer, I.; Stambolsky, P.; Shelly, A.; Goldfinger, N.; et al. Mutant p53(r175h) upregulates twist1 expression and promotes epithelial-mesenchymal transition in immortalized prostate cells. Cell Death Differ. 2011, 18, 271-281. [CrossRef] [PubMed]

109. Caramel, J.; Ligier, M.; Puisieux, A. Pleiotropic roles for zeb1 in cancer. Cancer Res. 2018, 78, 30-35. [CrossRef]

110. Selth, L.A.; Das, R.; Townley, S.L.; Coutinho, I.; Hanson, A.R.; Centenera, M.M.; Stylianou, N.; Sweeney, K.; Soekmadji, C.; Jovanovic, L.; et al. A zeb1-mir-375-yap1 pathway regulates epithelial plasticity in prostate cancer. Oncogene 2017, 36, 24-34. [CrossRef] [PubMed]

111. Putzke, A.P.; Ventura, A.P.; Bailey, A.M.; Akture, C.; Opoku-Ansah, J.; Celiktas, M.; Hwang, M.S.; Darling, D.S.; Coleman, I.M.; Nelson, P.S.; et al. Metastatic progression of prostate cancer and e-cadherin regulation by zeb1 and src family kinases. Am. J. Pathol. 2011, 179, 400-410. [CrossRef]

112. Furth, J.; Kahn, M.C.; Breedis, C. The transmission of leukemia of mice with a single cell. Am. J. Cancer 1937, 31, 276-282.

113. Ashworth, T. A case of cancer in which cells similar to those in tumors were seen in the blood after death. Aust. Med. J. 1869, 14, 146-149.

114. Paget, S. The distribution of secondary growths in cancer of the breast. Lancet 1989, 133, 571-573. [CrossRef]

115. Vanharanta, S.; Massague, J. Origins of metastatic traits. Cancer Cell 2013, 24, 410-421. [CrossRef] [PubMed]

116. Allard, W.J.; Matera, J.; Miller, M.C.; Repollet, M.; Connelly, M.C.; Rao, C.; Tibbe, A.G.; Uhr, J.W.; Terstappen, L.W. Tumor cells circulate in the peripheral blood of all major carcinomas but not in healthy subjects or patients with nonmalignant diseases. Clin. Cancer Res. 2004, 10, 6897-6904. [CrossRef] [PubMed]

117. Cristofanilli, M.; Budd, G.T.; Ellis, M.J.; Stopeck, A.; Matera, J.; Miller, M.C.; Reuben, J.M.; Doyle, G.V.; Allard, W.J.; Terstappen, L.W.; et al. Circulating tumor cells, disease progression, and survival in metastatic breast cancer. N. Engl. J. Med. 2004, 351, 781-791. [CrossRef]

118. Cohen, S.J.; Alpaugh, R.K.; Gross, S.; O’Hara, S.M.; Smirnov, D.A.; Terstappen, L.W.; Allard, W.J.; Bilbee, M.; Cheng, J.D.; Hoffman, J.P.; et al. Isolation and characterization of circulating tumor cells in patients with metastatic colorectal cancer. Clin. Colorectal Cancer 2006, 6, 125-132. [CrossRef]

119. Krebs, M.G.; Sloane, R.; Priest, L.; Lancashire, L.; Hou, J.M.; Greystoke, A.; Ward, T.H.; Ferraldeschi, R.; Hughes, A.; Clack, G.; et al. Evaluation and prognostic significance of circulating tumor cells in patients with non-small-cell lung cancer. J. Clin. Oncol. 2011, 29, 1556-1563. [CrossRef]

120. De Bono, J.S.; Scher, H.I.; Montgomery, R.B.; Parker, C.; Miller, M.C.; Tissing, H.; Doyle, G.V.; Terstappen, L.W.; Pienta, K.J.; Raghavan, D. Circulating tumor cells predict survival benefit from treatment in metastatic castration-resistant prostate cancer. Clin. Cancer Res. 2008, 14, 6302-6309. [CrossRef]

121. Liong, M.L.; Lim, C.R.; Yang, H.; Chao, S.; Bong, C.W.; Leong, W.S.; Das, P.K.; Loh, C.S.; Lau, B.E.; Yu, C.G.; et al. Blood-based biomarkers of aggressive prostate cancer. PLoS ONE 2012, 7, e45802. [CrossRef]

122. Zhou, L.; Dicker, D.T.; Matthew, E.; El-Deiry, W.S.; Alpaugh, R.K. Circulating tumor cells: Silent predictors of metastasis. F1000Research 2017, 6. [CrossRef]

123. Van Schaijik, B.; Wickremesekera, A.C.; Mantamadiotis, T.; Kaye, A.H.; Tan, S.T.; Stylli, S.S.; Itinteang, T. Circulating tumor stem cells and glioblastoma: A review. J. Clin. Neurosci. 2019, 61, 5-9. [CrossRef]

124. Micalizzi, D.S.; Maheswaran, S.; Haber, D.A. A conduit to metastasis: Circulating tumor cell biology. Genes Dev. 2017, 31, 1827-1840. [CrossRef]

125. Yang, M.H.; Imrali, A.; Heeschen, C. Circulating cancer stem cells: The importance to select. Chin. J. Cancer Res. Chung-Kuo Yen Cheng Yen Chiu 2015, 27, 437-449.

126. Baccelli, I.; Schneeweiss, A.; Riethdorf, S.; Stenzinger, A.; Schillert, A.; Vogel, V.; Klein, C.; Saini, M.; Bauerle, T.; Wallwiener, M.; et al. Identification of a population of blood circulating tumor cells from breast cancer patients that initiates metastasis in a xenograft assay. Nat. Biotechnol. 2013, 31, 539-544. [CrossRef]

127. Zhang, L.; Ridgway, L.D.; Wetzel, M.D.; Ngo, J.; Yin, W.; Kumar, D.; Goodman, J.C.; Groves, M.D.; Marchetti, D. The identification and characterization of breast cancer ctcs competent for brain metastasis. Sci. Transl. Med. 2013, 5, 180ra148. [CrossRef]

128. Grillet, F.; Bayet, E.; Villeronce, O.; Zappia, L.; Lagerqvist, E.L.; Lunke, S.; Charafe-Jauffret, E.; Pham, K.; Molck, C.; Rolland, N.; et al. Circulating tumour cells from patients with colorectal cancer have cancer stem cell hallmarks in ex vivo culture. Gut 2017, 66, 1802-1810. [CrossRef] 
129. Day, K.C.; Lorenzatti Hiles, G.; Kozminsky, M.; Dawsey, S.J.; Paul, A.; Broses, L.J.; Shah, R.; Kunja, L.P.; Hall, C.; Palanisamy, N.; et al. Her2 and egfr overexpression support metastatic progression of prostate cancer to bone. Cancer Res. 2017, 77, 74-85. [CrossRef]

130. Armstrong, A.J.; Marengo, M.S.; Oltean, S.; Kemeny, G.; Bitting, R.L.; Turnbull, J.D.; Herold, C.I.; Marcom, P.K.; George, D.J.; Garcia-Blanco, M.A. Circulating tumor cells from patients with advanced prostate and breast cancer display both epithelial and mesenchymal markers. Mol. Cancer Res. 2011, 9, 997-1007. [CrossRef]

131. Shiozawa, Y.; Nie, B.; Pienta, K.J.; Morgan, T.M.; Taichman, R.S. Cancer stem cells and their role in metastasis. Pharmacol. Ther. 2013, 138, 285-293. [CrossRef]

132. Harris, K.S.; Kerr, B.A. Prostate cancer stem cell markers drive progression, therapeutic resistance, and bone metastasis. Stem Cells Int. 2017, 2017, 8629234. [CrossRef]

133. Liu, H.; Patel, M.R.; Prescher, J.A.; Patsialou, A.; Qian, D.; Lin, J.; Wen, S.; Chang, Y.F.; Bachmann, M.H.; Shimono, Y.; et al. Cancer stem cells from human breast tumors are involved in spontaneous metastases in orthotopic mouse models. Proc. Natl. Acad. Sci. USA 2010, 107, 18115-18120. [CrossRef] [PubMed]

134. Pang, R.; Law, W.L.; Chu, A.C.; Poon, J.T.; Lam, C.S.; Chow, A.K.; Ng, L.; Cheung, L.W.; Lan, X.R.; Lan, H.Y.; et al. A subpopulation of cd26+ cancer stem cells with metastatic capacity in human colorectal cancer. Cell Stem Cell 2010, 6, 603-615. [CrossRef]

135. Saur, D.; Seidler, B.; Schneider, G.; Algul, H.; Beck, R.; Senekowitsch-Schmidtke, R.; Schwaiger, M.; Schmid, R.M. Cxcr4 expression increases liver and lung metastasis in a mouse model of pancreatic cancer. Gastroenterology 2005, 129, 1237-1250. [CrossRef]

136. Juarez, J.; Bendall, L. Sdf-1 and cxcr4 in normal and malignant hematopoiesis. Histol. Histopathol. 2004, 19, 299-309.

137. Karpova, D.; Bonig, H. Concise review: Cxcr4/cxcl12 signaling in immature hematopoiesis-lessons from pharmacological and genetic models. Stem Cells 2015, 33, 2391-2399. [CrossRef] [PubMed]

138. Domanska, U.M.; Kruizinga, R.C.; Nagengast, W.B.; Timmer-Bosscha, H.; Huls, G.; de Vries, E.G.; Walenkamp, A.M. A review on cxcr4/cxcl12 axis in oncology: No place to hide. Eur. J. Cancer 2013, 49, 219-230. [CrossRef] [PubMed]

139. Lombardi, L.; Tavano, F.; Morelli, F.; Latiano, T.P.; Di Sebastiano, P.; Maiello, E. Chemokine receptor cxcr4: Role in gastrointestinal cancer. Crit. Rev. Oncol./Hematol. 2013, 88, 696-705. [CrossRef]

140. Su, L.; Zhang, J.; Xu, H.; Wang, Y.; Chu, Y.; Liu, R.; Xiong, S. Differential expression of cxcr4 is associated with the metastatic potential of human non-small cell lung cancer cells. Clin. Cancer Res. 2005, 11, 8273-8280. [CrossRef]

141. Smith, M.C.; Luker, K.E.; Garbow, J.R.; Prior, J.L.; Jackson, E.; Piwnica-Worms, D.; Luker, G.D. Cxcr4 regulates growth of both primary and metastatic breast cancer. Cancer Res. 2004, 64, 8604-8612. [CrossRef] [PubMed]

142. Taichman, R.S.; Cooper, C.; Keller, E.T.; Pienta, K.J.; Taichman, N.S.; McCauley, L.K. Use of the stromal cell-derived factor-1/cxcr4 pathway in prostate cancer metastasis to bone. Cancer Res. 2002, 62, 1832-1837. [PubMed]

143. Jinnah, A.H.; Zacks, B.C.; Gwam, C.U.; Kerr, B.A. Emerging and established models of bone metastasis. Cancers 2018, 10, 176. [CrossRef]

144. Jung, Y.; Kim, J.K.; Shiozawa, Y.; Wang, J.; Mishra, A.; Joseph, J.; Berry, J.E.; McGee, S.; Lee, E.; Sun, H.; et al. Recruitment of mesenchymal stem cells into prostate tumours promotes metastasis. Nat. Commun. 2013, 4, 1795. [CrossRef] [PubMed]

145. Zhau, H.E.; He, H.; Wang, C.Y.; Zayzafoon, M.; Morrissey, C.; Vessella, R.L.; Marshall, F.F.; Chung, L.W.; Wang, R. Human prostate cancer harbors the stem cell properties of bone marrow mesenchymal stem cells. Clin. Cancer Res. 2011, 17, 2159-2169. [CrossRef] [PubMed]

146. Miki, J.; Furusato, B.; Li, H.; Gu, Y.; Takahashi, H.; Egawa, S.; Sesterhenn, I.A.; McLeod, D.G.; Srivastava, S.; Rhim, J.S. Identification of putative stem cell markers, cd133 and cxcr4, in htert-immortalized primary nonmalignant and malignant tumor-derived human prostate epithelial cell lines and in prostate cancer specimens. Cancer Res. 2007, 67, 3153-3161. [CrossRef]

147. Jeter, C.R.; Liu, B.; Liu, X.; Chen, X.; Liu, C.; Calhoun-Davis, T.; Repass, J.; Zaehres, H.; Shen, J.J.; Tang, D.G. Nanog promotes cancer stem cell characteristics and prostate cancer resistance to androgen deprivation. Oncogene 2011, 30, 3833-3845. [CrossRef] [PubMed] 
148. Jung, Y.; Cackowski, F.C.; Yumoto, K.; Decker, A.M.; Wang, J.; Kim, J.K.; Lee, E.; Wang, Y.; Chung, J.S.; Gursky, A.M.; et al. Cxcl12gamma promotes metastatic castration-resistant prostate cancer by inducing cancer stem cell and neuroendocrine phenotypes. Cancer Res. 2018, 78, 2026-2039. [CrossRef]

149. Kucia, M.; Reca, R.; Miekus, K.; Wanzeck, J.; Wojakowski, W.; Janowska-Wieczorek, A.; Ratajczak, J.; Ratajczak, M.Z. Trafficking of normal stem cells and metastasis of cancer stem cells involve similar mechanisms: Pivotal role of the sdf-1-cxcr4 axis. Stem Cells 2005, 23, 879-894. [CrossRef] [PubMed]

150. Liu, C.; Liu, R.; Zhang, D.; Deng, Q.; Liu, B.; Chao, H.P.; Rycaj, K.; Takata, Y.; Lin, K.; Lu, Y.; et al. Microrna-141 suppresses prostate cancer stem cells and metastasis by targeting a cohort of pro-metastasis genes. Nat. Commun. 2017, 8, 14270. [CrossRef]

151. Liu, C.; Kelnar, K.; Liu, B.; Chen, X.; Calhoun-Davis, T.; Li, H.; Patrawala, L.; Yan, H.; Jeter, C.; Honorio, S.; et al. The microrna mir-34a inhibits prostate cancer stem cells and metastasis by directly repressing cd 44 . Nat. Med. 2011, 17, 211-215. [CrossRef]

152. Ojo, D.; Lin, X.; Wong, N.; Gu, Y.; Tang, D. Prostate cancer stem-like cells contribute to the development of castration-resistant prostate cancer. Cancers 2015, 7, 2290-2308. [CrossRef]

153. Driessens, G.; Beck, B.; Caauwe, A.; Simons, B.D.; Blanpain, C. Defining the mode of tumour growth by clonal analysis. Nature 2012, 488, 527-530. [CrossRef]

154. Taussig, D.C.; Miraki-Moud, F.; Anjos-Afonso, F.; Pearce, D.J.; Allen, K.; Ridler, C.; Lillington, D.; Oakervee, H.; Cavenagh, J.; Agrawal, S.G.; et al. Anti-cd38 antibody-mediated clearance of human repopulating cells masks the heterogeneity of leukemia-initiating cells. Blood 2008, 112, 568-575. [CrossRef]

155. Zhang, W.C.; Shyh-Chang, N.; Yang, H.; Rai, A.; Umashankar, S.; Ma, S.; Soh, B.S.; Sun, L.L.; Tai, B.C.; Nga, M.E.; et al. Glycine decarboxylase activity drives non-small cell lung cancer tumor-initiating cells and tumorigenesis. Cell 2012, 148, 259-272. [CrossRef] [PubMed]

156. Beier, D.; Hau, P.; Proescholdt, M.; Lohmeier, A.; Wischhusen, J.; Oefner, P.J.; Aigner, L.; Brawanski, A.; Bogdahn, U.; Beier, C.P. Cd133(+) and cd133(-) glioblastoma-derived cancer stem cells show differential growth characteristics and molecular profiles. Cancer Res. 2007, 67, 4010-4015. [CrossRef]

157. Kanwal, R.; Shukla, S.; Walker, E.; Gupta, S. Acquisition of tumorigenic potential and therapeutic resistance in cd133+ subpopulation of prostate cancer cells exhibiting stem-cell like characteristics. Cancer Lett. 2018, 430, 25-33. [CrossRef] [PubMed]

158. Zhou, J.; Wang, H.; Cannon, V.; Wolcott, K.M.; Song, H.; Yates, C. Side population rather than cd133(+) cells distinguishes enriched tumorigenicity in htert-immortalized primary prostate cancer cells. Mol. Cancer 2011, 10, 112. [CrossRef]

159. Moreb, J.S.; Baker, H.V.; Chang, L.J.; Amaya, M.; Lopez, M.C.; Ostmark, B.; Chou, W. Aldh isozymes downregulation affects cell growth, cell motility and gene expression in lung cancer cells. Mol. Cancer 2008, 7, 87. [CrossRef] [PubMed]

160. Douville, J.; Beaulieu, R.; Balicki, D. Aldh1 as a functional marker of cancer stem and progenitor cells. Stem Cells Dev. 2009, 18, 17-25. [CrossRef]

161. Li, T.; Su, Y.; Mei, Y.; Leng, Q.; Leng, B.; Liu, Z.; Stass, S.A.; Jiang, F. Aldh1a1 is a marker for malignant prostate stem cells and predictor of prostate cancer patients' outcome. Lab. Investig. 2010, 90, 234-244. [CrossRef]

162. Nishida, S.; Hirohashi, Y.; Torigoe, T.; Inoue, R.; Kitamura, H.; Tanaka, T.; Takahashi, A.; Asanuma, H.; Masumori, N.; Tsukamoto, T.; et al. Prostate cancer stem-like cells/cancer-initiating cells have an autocrine system of hepatocyte growth factor. Cancer Sci 2013, 104, 431-436. [CrossRef]

163. Sefah, K.; Bae, K.M.; Phillips, J.A.; Siemann, D.W.; Su, Z.; McClellan, S.; Vieweg, J.; Tan, W. Cell-based selection provides novel molecular probes for cancer stem cells. Int. J. Cancer 2013, 132, 2578-2588. [CrossRef]

164. Le Magnen, C.; Bubendorf, L.; Rentsch, C.A.; Mengus, C.; Gsponer, J.; Zellweger, T.; Rieken, M.; Thalmann, G.N.; Cecchini, M.G.; Germann, M.; et al. Characterization and clinical relevance of aldhbright populations in prostate cancer. Clin. Cancer Res. 2013, 19, 5361-5371. [CrossRef]

165. Yan, J.; De Melo, J.; Cutz, J.C.; Aziz, T.; Tang, D. Aldehyde dehydrogenase 3a1 associates with prostate tumorigenesis. Br. J. Cancer 2014, 110, 2593-2603. [CrossRef]

166. Batlle, E.; Clevers, H. Cancer stem cells revisited. Nat. Med. 2017, 23, 1124-1134. [CrossRef]

167. Greten, F.R. Cancer: Tumour stem-cell surprises. Nature 2017, 543, 626-627. [CrossRef] 
168. De Sousa e Melo, F.; Kurtova, A.V.; Harnoss, J.M.; Kljavin, N.; Hoeck, J.D.; Hung, J.; Anderson, J.E.; Storm, E.E.; Modrusan, Z.; Koeppen, H.; et al. A distinct role for lgr5(+) stem cells in primary and metastatic colon cancer. Nature 2017, 543, 676-680. [CrossRef]

169. Mohyeldin, A.; Garzon-Muvdi, T.; Quinones-Hinojosa, A. Oxygen in stem cell biology: A critical component of the stem cell niche. Cell Stem Cell 2010, 7, 150-161. [CrossRef]

170. Naik, S.; Larsen, S.B.; Cowley, C.J.; Fuchs, E. Two to tango: Dialog between immunity and stem cells in health and disease. Cell 2018, 175, 908-920. [CrossRef]

171. Zhang, D.; Tang, D.G.; Rycaj, K. Cancer stem cells: Regulation programs, immunological properties and immunotherapy. Semin. Cancer Biol. 2018, 52, 94-106. [CrossRef]

172. Pazhanisamy, S.K. Stem cells, DNA damage, ageing and cancer. Hematol./Oncol. Stem Cell Ther. 2009, 2, 375-384. [CrossRef]

173. Lin, X.; Yan, J.; Tang, D. Erk kinases modulate the activation of pi3 kinase related kinases (pikks) in DNA damage response. Histol. Histopathol. 2013, 28, 1547-1554. [PubMed]

174. Wei, F.; Yan, J.; Tang, D. Extracellular signal-regulated kinases modulate DNA damage response-a contributing factor to using mek inhibitors in cancer therapy. Curr. Med. Chem. 2011, 18, 5476-5482. [CrossRef]

175. Burkhalter, M.D.; Rudolph, K.L.; Sperka, T. Genome instability of ageing stem cells-induction and defence mechanisms. Ageing Res. Rev. 2015, 23, 29-36. [CrossRef]

176. Fan, C.; Quan, R.; Feng, X.; Gillis, A.; He, L.; Matsumoto, E.D.; Salama, S.; Cutz, J.C.; Kapoor, A.; Tang, D. Atm activation is accompanied with earlier stages of prostate tumorigenesis. Biochim. Biophys. Acta 2006, 1763, 1090-1097. [CrossRef]

177. Park, I.K.; Morrison, S.J.; Clarke, M.F. Bmi1, stem cells, and senescence regulation. J. Clin. Investig. 2004, 113, 175-179. [CrossRef] [PubMed]

178. Park, I.K.; Qian, D.; Kiel, M.; Becker, M.W.; Pihalja, M.; Weissman, I.L.; Morrison, S.J.; Clarke, M.F. Bmi-1 is required for maintenance of adult self-renewing haematopoietic stem cells. Nature 2003, 423, 302-305. [CrossRef]

179. Molofsky, A.V.; He, S.; Bydon, M.; Morrison, S.J.; Pardal, R. Bmi-1 promotes neural stem cell self-renewal and neural development but not mouse growth and survival by repressing the p16INK4a and p19ARF senescence pathways. Genes Dev. 2005, 19, 1432-1437. [CrossRef] [PubMed]

180. Molofsky, A.V.; Pardal, R.; Iwashita, T.; Park, I.K.; Clarke, M.F.; Morrison, S.J. Bmi-1 dependence distinguishes neural stem cell self-renewal from progenitor proliferation. Nature 2003, 425, 962-967. [CrossRef]

181. Bruggeman, S.W.; Valk-Lingbeek, M.E.; van der Stoop, P.P.; Jacobs, J.J.; Kieboom, K.; Tanger, E.; Hulsman, D.; Leung, C.; Arsenijevic, Y.; Marino, S.; et al. INK4a and ARF differentially affect cell proliferation and neural stem cell self-renewal in bmi1-deficient mice. Genes Dev. 2005, 19, 1438-1443. [CrossRef]

182. Oguro, H.; Iwama, A.; Morita, Y.; Kamijo, T.; van Lohuizen, M.; Nakauchi, H. Differential impact of ink4a and arf on hematopoietic stem cells and their bone marrow microenvironment in bmi1-deficient mice. J. Exp. Med. 2006, 203, 2247-2253. [CrossRef]

183. Sangiorgi, E.; Capecchi, M.R. Bmi1 is expressed in vivo in intestinal stem cells. Nat. Genet. 2008, 40, 915-920. [CrossRef]

184. Yan, K.S.; Chia, L.A.; Li, X.; Ootani, A.; Su, J.; Lee, J.Y.; Su, N.; Luo, Y.; Heilshorn, S.C.; Amieva, M.R.; et al. The intestinal stem cell markers bmi1 and lgr5 identify two functionally distinct populations. Proc. Natl. Acad. Sci. USA 2012, 109, 466-471. [CrossRef]

185. Siddique, H.R.; Saleem, M. Role of bmi1, a stem cell factor, in cancer recurrence and chemoresistance: Preclinical and clinical evidences. Stem Cells 2012, 30, 372-378. [CrossRef]

186. Lin, X.; Gu, Y.; Tang, D. Bmi1, atm and ddr. Oncoscience 2015, 2, 665-666.

187. Lin, X.; Wei, F.; Whyte, P.; Tang, D. Bmi1 reduces atr activation and signalling caused by hydroxyurea. Oncotarget 2017, 8, 89707-89721. [CrossRef]

188. Wei, F.; Ojo, D.; Lin, X.; Wong, N.; He, L.; Yan, J.; Xu, S.; Major, P.; Tang, D. Bmi1 attenuates etoposide-induced $\mathrm{g} 2 / \mathrm{m}$ checkpoints via reducing atm activation. Oncogene 2015, 34, 3063-3075. [CrossRef]

189. Yan, J.; Tang, D. Prostate cancer stem-like cells proliferate slowly and resist etoposide-induced cytotoxicity via enhancing DNA damage response. Exp. Cell Res. 2014, 328, 132-142. [CrossRef]

190. Wainwright, E.N.; Scaffidi, P. Epigenetics and cancer stem cells: Unleashing, hijacking, and restricting cellular plasticity. Trends Cancer 2017, 3, 372-386. [CrossRef] 
191. Simon, J.A.; Lange, C.A. Roles of the ezh2 histone methyltransferase in cancer epigenetics. Mutat Res 2008, 647, 21-29. [CrossRef] [PubMed]

192. Suva, M.L.; Riggi, N.; Janiszewska, M.; Radovanovic, I.; Provero, P.; Stehle, J.C.; Baumer, K.; Le Bitoux, M.A.; Marino, D.; Cironi, L.; et al. Ezh2 is essential for glioblastoma cancer stem cell maintenance. Cancer Res. 2009, 69, 9211-9218. [CrossRef] [PubMed]

193. Li, K.; Liu, C.; Zhou, B.; Bi, L.; Huang, H.; Lin, T.; Xu, K. Role of ezh2 in the growth of prostate cancer stem cells isolated from lncap cells. Int. J. Mol. Sci. 2013, 14, 11981-11993. [CrossRef]

194. Liu, R.; Liu, C.; Zhang, D.; Liu, B.; Chen, X.; Rycaj, K.; Jeter, C.; Calhoun-Davis, T.; Li, Y.; Yang, T.; et al. Mir-199a-3p targets stemness-related and mitogenic signaling pathways to suppress the expansion and tumorigenic capabilities of prostate cancer stem cells. Oncotarget 2016, 7, 56628-56642. [CrossRef]

195. Chakraborty, C.; Chin, K.Y.; Das, S. Mirna-regulated cancer stem cells: Understanding the property and the role of mirna in carcinogenesis. Tumour. Biol. 2016, 37, 13039-13048. [CrossRef]

196. Ocana, O.H.; Corcoles, R.; Fabra, A.; Moreno-Bueno, G.; Acloque, H.; Vega, S.; Barrallo-Gimeno, A.; Cano, A.; Nieto, M.A. Metastatic colonization requires the repression of the epithelial-mesenchymal transition inducer prrx1. Cancer Cell 2012, 22, 709-724. [CrossRef]

197. Jordan, N.V.; Johnson, G.L.; Abell, A.N. Tracking the intermediate stages of epithelial-mesenchymal transition in epithelial stem cells and cancer. Cell Cycle 2011, 10, 2865-2873. [CrossRef] [PubMed]

198. Sannino, G.; Marchetto, A.; Kirchner, T.; Grunewald, T.G.P. Epithelial-to-mesenchymal and mesenchymal-to-epithelial transition in mesenchymal tumors: A paradox in sarcomas? Cancer Res. 2017, 77, 4556-4561. [CrossRef] [PubMed]

199. Lee, S.O.; Ma, Z.; Yeh, C.R.; Luo, J.; Lin, T.H.; Lai, K.P.; Yamashita, S.; Liang, L.; Tian, J.; Li, L.; et al. New therapy targeting differential androgen receptor signaling in prostate cancer stem/progenitor vs. Non-stem/progenitor cells. J. Mol. Cell Biol. 2013, 5, 14-26. [CrossRef]

200. Lin, Y.C.; Murayama, Y.; Hashimoto, K.; Nakamura, Y.; Lin, C.S.; Yokoyama, K.K.; Saito, S. Role of tumor suppressor genes in the cancer-associated reprogramming of human induced pluripotent stem cells. Stem Cell Res 2014, 5, 58. [CrossRef] [PubMed]

201. Barbieri, C.E.; Baca, S.C.; Lawrence, M.S.; Demichelis, F.; Blattner, M.; Theurillat, J.P.; White, T.A.; Stojanov, P.; Van Allen, E.; Stransky, N.; et al. Exome sequencing identifies recurrent spop, foxa1 and med12 mutations in prostate cancer. Nat. Genet. 2012, 44, 685-689. [CrossRef]

202. Blattner, M.; Lee, D.J.; O’Reilly, C.; Park, K.; MacDonald, T.Y.; Khani, F.; Turner, K.R.; Chiu, Y.L.; Wild, P.J.; Dolgalev, I.; et al. Spop mutations in prostate cancer across demographically diverse patient cohorts. Neoplasia 2014, 16, 14-20. [CrossRef]

203. Boysen, G.; Barbieri, C.E.; Prandi, D.; Blattner, M.; Chae, S.S.; Dahija, A.; Nataraj, S.; Huang, D.; Marotz, C.; $\mathrm{Xu}$, L.; et al. SPOP mutation leads to genomic instability in prostate cancer. eLife 2015, 4. [CrossRef]

204. Xie, Y.; Zheng, L.; Tao, L. Downregulation of iqgap2 correlates with prostate cancer recurrence and metastasis. Transl. Oncol. 2019, 12, 236-244. [CrossRef]

205. Zhang, J.; Chen, M.; Zhu, Y.; Dai, X.; Dang, F.; Ren, J.; Ren, S.; Shulga, Y.V.; Beca, F.; Gan, W.; et al. SPOP promotes NANOG destruction to suppress stem cell traits and prostate cancer progression. Dev. Cell 2019, 48, 329-344.e5. [CrossRef]

206. Wang, X.; Jin, J.; Wan, F.; Zhao, L.; Chu, H.; Chen, C.; Liao, G.; Liu, J.; Yu, Y.; Teng, H.; et al. AMPK promotes Spop-mediated NANOG degradation to regulate prostate cancer cell stemness. Dev. Cell 2018. [CrossRef]

207. Lin, C.J.; Lo, U.G.; Hsieh, J.T. The regulatory pathways leading to stem-like cells underlie prostate cancer progression. Asian J. Androl. 2019, 48, 345-360.e7.

208. Robinson, D.; Van Allen, E.M.; Wu, Y.M.; Schultz, N.; Lonigro, R.J.; Mosquera, J.M.; Montgomery, B.; Taplin, M.E.; Pritchard, C.C.; Attard, G.; et al. Integrative clinical genomics of advanced prostate cancer. Cell 2015, 161, 1215-1228. [CrossRef]

209. Zou, M.; Toivanen, R.; Mitrofanova, A.; Floch, N.; Hayati, S.; Sun, Y.; Le Magnen, C.; Chester, D.; Mostaghel, E.A.; Califano, A.; et al. Transdifferentiation as a mechanism of treatment resistance in a mouse model of castration-resistant prostate cancer. Cancer Discov. 2017, 7, 736-749. [CrossRef]

210. Akamatsu, S.; Inoue, T.; Ogawa, O.; Gleave, M.E. Clinical and molecular features of treatment-related neuroendocrine prostate cancer. Int. J. Urol. 2018, 25, 345-351. [CrossRef] 
211. Ku, S.Y.; Rosario, S.; Wang, Y.; Mu, P.; Seshadri, M.; Goodrich, Z.W.; Goodrich, M.M.; Labbe, D.P.; Gomez, E.C.; Wang, J.; et al. Rb1 and trp53 cooperate to suppress prostate cancer lineage plasticity, metastasis, and antiandrogen resistance. Science 2017, 355, 78-83. [CrossRef]

212. Soundararajan, R.; Aparicio, A.M.; Logothetis, C.J.; Mani, S.A.; Maity, S.N. Function of tumor suppressors in resistance to antiandrogen therapy and luminal epithelial plasticity of aggressive variant neuroendocrine prostate cancers. Front. Oncol. 2018, 8, 69. [CrossRef]

213. Soundararajan, R.; Paranjape, A.N.; Maity, S.; Aparicio, A.; Mani, S.A. Emt, stemness and tumor plasticity in aggressive variant neuroendocrine prostate cancers. Biochim. Biophys. Acta. Rev. Cancer 2018, 1870, 229-238. [CrossRef]

214. Park, J.W.; Lee, J.K.; Sheu, K.M.; Wang, L.; Balanis, N.G.; Nguyen, K.; Smith, B.A.; Cheng, C.; Tsai, B.L.; Cheng, D.; et al. Reprogramming normal human epithelial tissues to a common, lethal neuroendocrine cancer lineage. Science 2018, 362, 91-95. [CrossRef]

215. Sarig, R.; Rivlin, N.; Brosh, R.; Bornstein, C.; Kamer, I.; Ezra, O.; Molchadsky, A.; Goldfinger, N.; Brenner, O.; Rotter, V. Mutant p53 facilitates somatic cell reprogramming and augments the malignant potential of reprogrammed cells. J. Exp. Med. 2010, 207, 2127-2140. [CrossRef]

216. Mu, P.; Zhang, Z.; Benelli, M.; Karthaus, W.R.; Hoover, E.; Chen, C.C.; Wongvipat, J.; Ku, S.Y.; Gao, D.; Cao, Z.; et al. Sox 2 promotes lineage plasticity and antiandrogen resistance in tp53- and rb1-deficient prostate cancer. Science 2017, 355, 84-88. [CrossRef]

217. Karthaus, W.R.; Sawyers, C.L. Strategies to identify and target cells of origin in prostate cancer. J. Natl. Cancer Inst. 2019, 111, 221-223. [CrossRef]

(C) 2019 by the authors. Licensee MDPI, Basel, Switzerland. This article is an open access article distributed under the terms and conditions of the Creative Commons Attribution (CC BY) license (http://creativecommons.org/licenses/by/4.0/). 